\title{
A aparição do demônio no Catulé*
}

\section{Carlo Castaldi}

Os jornais de 14 de abril de 1955 noticiaram que, no lugar chamado Catulé, na fazenda São João da Mata, município de Malacacheta, um grupo de meeiros, membros da Igreja Adventista da Promessa, havia morto quatro crianças, acusadas de estarem possuídas pelo demônio.

O presente trabalho, que reúne o material coletado durante nossas visitas ao Catulé, é uma história objetiva desses acontecimentos. Acreditamos ter conseguido reconstituí-los, mas queremos lembrar que as ligaçôes entre os fatos se prendem mais a uma série de associações do que a uma sequiência lógica de causas.

A distância que separa a fazenda de São João da Mata ou "fazenda Itatiaia" da cidade de Malacacheta é de três léguas.

A meia légua da sede da fazenda, encontra-se uma clareira chamada Catulé.

Em abril deste ano dez famílias habitavam o local. As mais antigas haviam-se mudado para o Catulé três anos antes. Nos anos sucessivos, chegaram outras, ligadas às primeira por vínculos de parentesco ou amizade (ver Diagrama, p. 351). Duas - a de Onofre do S. e a de Joaquim da C. tinham voltado havia pouco da cidade paulista de Presidente Prudente. Emigraram a fim de trabalhar nas plantações de algodão, e lá foram convertidos à Igreja Adventista da Promessa.

Onofre chegou primeiro e logo iniciou um trabalho missionário no Catulé. Joaquim veio depois e ambos se tornaram os líderes da nova seita,
${ }^{*}$ Este artigo foi publicado em Estudos de sociologia e história, de Maria Izaura Pereira $e t$ al. São Paulo, Inep/ Anhembi, 1957. 
1. O "batismo do Espírito Santo" - a experiência mais significativa do Adventismo pode acontecer a qualquer pessoa, em qualquer momento e em qualquer lugar. $\mathrm{O}$ Espírito Santo não somente "sela" a alma do crente para a salvação, como pode dotá-la dos seguintes "dons": sabedoria, ciência, fé, os dons de curar, operação de maravilhas, a profecia, discernimento dos espíritos, variedade de línguas, interpretação das línguas (Igreja Adventista da Promessa, Manual dos trinta pontos preliminares de nossa fé, São Paulo, Departamento de publicaçóes da Igreja Adventista da Promessa, s. d., p. 30).

2.O "batismo das águas", que consiste na imersão total da pessoa, é recebido geralmente depois dos 16 anos e simboliza a renúncia consciente ao mundo e suas vaidades. A cerimônia da Santa Ceia reproduz a Última Ceia, mas o vinho é substituído por suco de uva e não se admite a transubstanciação. que se estendeu a diversos grupos vizinhos. Começaram a pregar a vinda de Cristo, incitando os novos prosélitos a levar uma vida "justa", a fim de estarem preparados para o segundo advento. Tinham que respeitar os dez mandamentos, sendo também proibido fumar, beber e comer carne de certos animais, como por exemplo o porco. Deviam trabalhar, viver honestamente, e considerar sagrado o dia do sábado. Obtiveram êxito em sua pregação e logo converteram todo o grupo, que passou a ter vida religiosa muito intensa. Reuniam-se regularmente para orar, três vezes por semana, às quartas, sextas e domingos de noite, na casa de um ou outro dentre eles. Aos sábados, pela manhã, celebravam o culto na casa de oração, a uma hora de marcha da clareira e a meio caminho dos outros grupos.

Onofre, o único que sabia ler e escrever, procedia à leitura e à explicação dos textos bíblicos e auxiliava os irmãos a decorar passagens da Bíblia e hinos. Qualquer um podia dirigir as oraçôes; cabia porém a Joaquim e Onofre marcar os dias de jejum e determinar a confissão pública dos pecados. Durante tais reuniões podia acontecer que os crentes de bom testemunho e fé poderosa fossem "selados" pelo Espírito Santo".

$\mathrm{O}$ primeiro contato com representantes oficiais da Igreja Adventista da Promessa deu-se, ao que sabemos, em outubro de 1954, quando dois pastores visitaram aquela área, a fim de orientar os vários grupos de adventistas que se iam formando. Durante essa visita, os pastores celebraram pela primeira vez o batismo das águas e a Santa Ceia, duas cerimônias que só pessoas qualificadas podem executar ${ }^{2}$.

No número de outubro do Jornal Oficial da Igreja, O Restaurador Mensário Doutrinário Informativo, encontramos, com a assinatura de Adelino C. da Cruz, o seguinte artigo:

Viagem a Malacacheta - Minas, Belo Horizonte - 5-10-54. Eu e o irmão Julino voltamos de Malacacheta no dia 29-9-54. A viagem não foi fácil como imaginávamos. A distância e a falta de controle dos transportes tornaram aquele percurso longo e dispendioso. Viajamos de trem, de ônibus, de caminhão até chegar a Malacacheta. Não terminou aí a jornada. Ficamos cientes de que tínhamos mais bons $24 \mathrm{kms}$ para vencer, a pé, até chegar à fazenda, onde residem nossos irmãos. Nesse trecho nossas malas foram na carga de um burro, que é o meio de transporte do lugar. Tomamos um trilho e fomos: ora subindo, ora contornando, ora descendo as altas montanhas, as quais formam as paisagens que ali são naturais. Quase em meio do caminho entramos na casa de um sr. fazendeiro chamado Felipe, na residência do qual fomos servidos com água e café. Palestramos ligeiramente. Prosse- 
guimos a viagem e às 16 horas exatamente chegamos ao destino tomado três dias antes. Os irmãos demonstraram muita alegria pela nossa chegada. Ficamos sabendo que o número de crentes era de 40, sem contar os menores. Havia 20 batizados com Espírito Santo. No primeiro culto que fizemos houve um selamento. Glória a Deus. Isto se deu da quinta-feira para a sexta-feira. No sábado passaram pelas águas batismais 7 pessoas. No apelo que fizemos durante a reunião da noite recebemos mais 12 pessoas as quais se entregaram ao Redentor de nossas almas. No domingo de manhã voltamos a Malacacheta em companhia de toda a congregação. Entramos novamente na residência do sr. Felipe, mas desta vez a casa encheu-se de crentes. Oportunamente cantamos hinos. $\mathrm{O}$ irmão Julino fez diversas explicações da palavra de Deus, pelo que o sr. Felipe demonstrou muito interesse e nos tratou muito cortesmente. À noite chegamos à cidade e logo tínhamos à disposição a casa de uma pessoa amiga dos irmãos para a reunião da noite. A reunião foi muito concorrida de visitas curiosas e muito respeitada pela família da casa. Nesse culto houve pregação do Evangelho e Santa Ceia e depois vigília. Na segunda-feira cedo nos despedimos daqueles esforçados irmãos com saudades dos 4 dias e 5 reuniōes alegres. Temos o prazer de anunciar que temos dois grupos de crentes que prometem o progresso da promessa no interior daquele estado. Aquele trabalho teve início na instrumentalidade de um jovem, que é o irmão Onofre Antônio Gomes, pessoa esforçada e de bom testemunho.

Tendo estabelecido contatos mais diretos com a sede central da Igreja, localizada em São Paulo, o culto pareceu assumir o caráter de uma organização mais formal. Iniciou-se a construção da casa de oração, estando Onofre encarregado de coletar os dízimos e as ofertas, que marcava nos recibos impressos distribuídos pela Igreja.

A partir dessa data, os dirigentes da seita resolveram enviar para aquela zona uma pessoa que pudesse orientar e dirigir os vários religiosos:

São Paulo, 21-11-54.

Prezados irmãos em Cristo. - Grupo de Malacacheta, estado de Minas Gerais.

Nós os pastores dirigentes da Igreja Adventista da Promessa estamos de posse de boas notícias a vosso respeito. Alegramo-nos em ver como Deus tem maravilhosamente operado com o seu santo braço valorosamente salvando tantas almas preciosas do poder do pecado. Temos portanto um grande e animado grupo de crentes aí em Malacacheta com o qual esperamos em Deus ver outras almas ganhas para o reino de Deus. Portanto tendes agora uma gloriosa tarefa, é dizer, pregar as verdades do Evangelho de Jesus Cristo, pelo poder o Espírito Santo. 
3. Geraldo Justiniano não limitava sua ação à propaganda religiosa, mas cuidou também de alfabetizar os crentes. Transcrevemos uma carta da Confederação Evangélica, em resposta ao seu pedido de material para organizar uma escola: "Ilmo Sr. Geraldo Justiniano a/c do sr. Joaquim Gato. Malacacheta. Via Teófilo Otoni, Estado de Minas Gerais. Rio de janeiro, 15-3-55. Prezado irmão em Cristo, saudaçôes. Estamos respondendo a sua carta do 3 do corrente com a qual nos comunica estar grandemente interessado na alfabetização de adolescentes e adultos, propondo-se organizar um curso ou escola com probabilidades de matricular cem alunos. Para que o irmão nos possa fornecer mais completas informaçōes e também melhor se inteirar acerca do nosso serviço e dos objetivos da Campanha de Alfabetização e de Educação dos adolescentes e adultos, é que nós lhe estamos enviando uma folha mimeografada que se encontra anexada a esta com todas as informações
Certamente haveis de ficar contentes e alegres em saber que irá residir aí em vosso meio um de nossos irmãos aliás bem experimentado, e de bom testemunho. Ele não é um pastor, e nem obreiro ainda, mas nós recomendamos que esse irmão, que é o irmão Geraldo Justiniano, o qual é membro do conselho central da Igreja, seja considerado por todos, e seja o vosso dirigente espiritual até que outras medidas e circunstâncias assim modifique a situação.

Segue uma fotografia do nosso enviado o qual também apresentará, quando aí chegar, uma credencial com a sua fotografia e assinada por nós.

Dos vossos cooperadores em Cristo, sempre ao vosso inteiro dispor. (aa) João Augusto da Silveira, G. R. Wanderley

Geraldo Justiniano chegou em fevereiro e continuou a obra de proselitismo que Onofre e Joaquim haviam iniciado ${ }^{3}$.

Quer durante o crescimento espontâneo do culto, quer durante a difusão orientada pela seita, o grupo do Catulé sempre levou uma vida trabalhadora e honesta, que lhe granjeou o apreço do fazendeiro e de todos aqueles com quem mantinha relações.

Esse ritmo de vida pacata quebra-se, súbita e inexplicavelmente, no momento em que é revelada a presença de Satanás no grupo, conforme a seqüência que passamos a expor ${ }^{4}$.

\section{Os fatos}

Onofre e Geraldo J. haviam marcado para a primeira semana de abril uma viagem de proselitismo ao Tabocal, povoado distante algumas léguas do Catulé. Como todas as viagens de proselitismo, também esta foi precedida de uma "semana de oração" durante a qual o grupo se preparou espiritualmente para a ocasião através da reza e do pedido de perdão aos que haviam sido ofendidos. A "semana da oração" começara sexta-feira, 1ํ de abril de 1955, e na quinta-feira seguinte, dia 7 de abril, iniciaram a viagem. Quinta-feira pernoitariam na casa de Onório C., que servia de centro de reunião aos "crentes" de além rio Urupuca, para no dia seguinte prosseguir o caminho de modo a chegar ao Tabocal antes da "entrada do sábado". Terça-feira, 2 de abril, pela manhã, Geraldo J. deixou Catulé porque havia decidido dedicar a terça e a quarta aos cuidados do grupo do Urupuca: na quinta-feira Onofre e os demais iriam ter com ele e todos juntos continuariam a viagem.

Na mesma manhã em que Geraldo partiu, Joaquim aviou-se para a casa de Manuel S. com a intenção de fazer as pazes com ele. De fato, as relações 
de Joaquim com o velho Manuel estavam tensas há tempo. Segundo Manuel, Joaquim começou a "persegui-lo" desde o primeiro momento em que chegou ao grupo. Manuel conta que então morava numa casa "pegada" à de Onofre; essa vizinhança era agradável a Manuel porque lhe permitia participar, mais intimamente que qualquer outro membro do grupo, da vida daquele que o estava substituindo na sua posição de chefe. Quando Joaquim e a família se transferiram para Catulé, construíram a sua casa perto da de Onofre, mas do lado contrário à de Manuel. Joaquim, diz Manuel, aproveitou essa vizinhança para se intrometer na sua vida particular. Criticava, por exemplo, o modo por que Manuel criava sua filha Ana, censurava o seu comportamento e chamava a atenção de Onofre para os seus eventuais erros de conduta como "irmão". Manuel, com seus 64 anos, não podia aceitar, de coração sereno, as críticas de um moço de 26 e além do mais estranho; tal relutância de Manuel em aceitar passivamente as críticas de Joaquim dava a este último o ensejo de indicar a Onofre e aos demais membros do grupo a má vontade do "velho" em aceitar os bons conselhos de um seu "irmão". A conversão ao adventismo, com efeito, alterara profundamente as relações tradicionais entre Manuel, o antigo chefe do grupo, e os seus componentes, porque pelo fato de se tornarem todos "irmãos", Manuel encontrara-se em pé de igualdade com todos os adultos do Catulé; e além disso, como "irmão", vinha a ser subordinado aos que tinham um conhecimento mais profundo da nova doutrina, isto é, Onofre e Joaquim, dois jovens de 26 anos apenas. Mas se Onofre continuava a reconhecer ao "velho" o prestígio que conquistara como antigo chefe do grupo, Joaquim não estava ligado a Manuel por vínculos semelhantes; ao contrário, era levado a ser-lhe hostil, pois via em Manuel a pessoa que podia consertar-lhe a posição de vice-chefe, que ele próprio queria ocupar.

A situação chegou a tal ponto que Manuel, para subtrair-se à insistente censura de Joaquim, construiu uma casa um pouco afastada das outras. Porém a casa estava no limite de uma roçada que Manuel "vendera" a Joaquim quando este, chegado ao Catulé, procurara um pedaço de terra já pronto para cultivar. Terminada a construção da casa, logo surgiram litígios de divisas, Manuel acusava Joaquim de ter plantado além do seu limite, Joaquim acusava Manuel de ter-se instalado onde não devia.

Terça-feira de manhã, pois, Joaquim dirigiu-se a Manuel para tentar, como contou depois, fazer as pazes, Manuel estava lendo a Bíblia quando Joaquim chegou. Interrompeu a leitura e, cumprimentando-o, perguntou em que lhe podia ser útil. Joaquim disse que viera para que se perdoassem necessárias e para a qual pedimos a sua especial atenção em todos os seus itens, e parágrafos. Aguardamos, vivamente interessados, a sua resposta indicando-nos o número de alunos matriculados, o grau de adiantamento dos alunos, o método que usará (se o ensino individual ou em classes mistas de mais de cinco alunos) e a quantidade de material escolar de que necessita para o início do seu trabalho de alfabetização. Para um elevado número de alunos e um trabalho mais eficiente, é aconselhável dividir-se em turmas até 25 ou 30 alunos no máximo. Assim, haveria um ou mais de um professor ou então aulas em turnos diferentes. Com os nossos... (a) - Rodolfo Anders".

4. Os fatos que passamos a relatar desenrolaram-se durante a Semana Santa, mas não parece que a significação cristã desses dias tenha influído nos acontecimentos.

5. "Vender roçado" quer dizer vender o trabalho necessário para preparar a terra e não, naturalmente, a própria terra. 
mutuamente antes de encetar a viagem. $\mathrm{O}$ pedido de perdão, note-se, não implicava um reconhecimento dos pecados para os quais se pediam desculpas. Manuel respondeu que nada tinha a perdoar, e Joaquim acusou-o de ter um coração duro. Manuel, zangado, deixou Joaquim e encaminhou-se ao seu mandiocal. Joaquim chamou Hermínia, a mulher de Manuel, e Ana, a filha, que estavam em casa, e convidou-as a rezar com ele para que o Senhor abrandasse o coração de Manuel. Aqueles que, ignorando o que se passava, estavam na clareira, ouviram, de repente, os gritos de Joaquim, provenientes da casa de Manuel. Correram para ver o que era, pensando que Joaquim "houvesse sido mordido de cobra. Encontraram Joaquim, Ana e Hermínia ajoelhados no terreiro, todos trespassados. Joaquim chorava e gritava”. A violência da crise atraiu ao lugar o próprio Manuel, que a provocara. Ele não quisera aceitar as propostas de paz de um "irmão", e a prova da sinceridade dessas propostas estava no fato de ter o Espírito Santo descido sobre Joaquim, e o Espírito Santo não desce sobre pessoas de corações impuros. Além disso, a adesão da mulher e da filha de Manuel às orações de Joaquim indicava que estas achavam necessário unir os seus votos aos de Joaquim a fim de que o Senhor abrandasse a alma do velho. Manuel viu-se obrigado a conceder aquele perdão que antes se recusara a dar, e também a receber o de Joaquim pelo que acontecera entre eles e pela sua obstinação. De volta à casa, Joaquim deteve-se para falar com Geraldo A. P., genro de Manuel e um dos mais fervorosos membros da nova seita, para contar-lhe o ocorrido. Fora uma "oração muito brava. O Espírito Santo foi forte, mas o velho tinha perdoado". De noite, na casa de Geraldo A. P., onde costumavam reunir-se para orar, Onofre quis que Manuel e Joaquim se perdoassem mutuamente uma vez mais; "o velho pediu perdão", diz um dos nossos informantes, "mas a gente não sabe se era de coração".

Que a dúvida se justificasse, parece confirmado pelo fato de Geraldo A. P., quarta-feira pela manhã, indo ajudar Sebastião, outro genro de Manuel, na sua roça, ter encontrado Manuel, que lhe comunicou sua intenção de formar, pelo menos é o que diz Manuel, uma "comissão" para julgar a sua disputa com Joaquim. Geraldo, como resposta, não só se recusou a ajudá-lo, mas começou a gritar "Em nome de Jesus Nazaré, sai Satanás, sai Satanás". A versão do fato dada por Geraldo é diferente; conta ele que Manuel não disse uma palavra do seu propósito de formar uma comissão, mas limitou-se a acusar Joaquim, bom amigo de Geraldo, o qual achou diabólica essa obstinação de Manuel que na véspera à noite perdoara. Essa discussão entre Manuel e seu genro revela claramente como a nova religião havia mudado as 
relações tradicionais entre as pessoas do grupo, pois as alianças baseadas em vínculos familiais são substituídas pela comunhão de seita. Não só Geraldo A. P. defendeu Joaquim contra o sogro mas julgou seu dever informar este último sobre o ocorrido. À noite, terminada a cerimônia do culto, Joaquim pediu de novo a Manuel, com muita insistência, que o perdoasse, porém Manuel não estava disposto a admitir a inconseqüência do seu comportamento, isto é, do perdão concedido terça-feira com o pedido de formar-se uma comissão, por ele formulado quarta-feira pela manhã; e respondeu a Joaquim: "O deus de ontem não é o deus de hoje?" pelo que não via a necessidade de repetir o perdão. Como que exasperado pelo comportamento de Manuel, Joaquim agarrou-o e sacudiu-o. Embora fosse possível para o grupo, como grupo de crentes, identificar-se com o comportamento de Joaquim, o qual, na sua última disputa com Manuel, se mantivera do lado da razão, é certamente difícil entender por que nenhum dos presentes, e sobretudo Onofre, censurou aquele ato de violência, o primeiro, ao que parece, praticado por um membro do grupo contra um confrade. Ao contrário, Onofre aconselhou Manuel a "agüentar" e este, sem comentários ulteriores, deixou a reunião, seguido pela mulher e pela filha. À pergunta que fizemos sobre o motivo por que ninguém interviera, a resposta foi invariavelmente “porque Onofre não interveio", e por que Onofre não o fez, é uma questão à qual somente Onofre poderia responder, admitindo que tivesse querido fazê-lo. Mas o fato de Onofre não ter censurado o gesto de Joaquim deve ter dado a este último um certo senso de imunidade em suas ações. Depois da saída de Manuel, recomeçaram a rezar. "Estávamos no fim do culto" narra um dos habitantes do Catulé, "e todos estávamos dirigindo oração". Maria dos Anjos ${ }^{6}$ estava cochilando, ajoelhada na soleira da porta e "não dirigiu". Artuliana (irmã de Joaquim) disse que "era o Satanás que estava empatando" e de repente Joaquim pulou sobre a dos Anjos e começou a batê-la para "expulsar o Satanás". Este, segundo ato de violência de Joaquim tampouco encontrou censura; Onofre e os demais aceitaram sem comentários não só o ato mas a sua justificação: "bateu nela para expulsar Satanás". Satanás, pois, era para todos uma realidade tão plausível que nem sequer se punha em dúvida, assim como se considerava uma possibilidade concreta cair vítima de suas tentações ou ser diretamente possuído por ele. Quando Joaquim soltou a moça, esta não fugiu, mas voltou para a casa dos B., onde morava, e foi dormir. Mal tinham começado a dispersar-se quando Geraldo R. dos S. gritou que Satanás aparecera no seu terreiro. Todos correram para ver, e ele indicou um pedaço de rapadura dizendo que surgira misteriosamente. In-
6. Maria dos Anjos era uma menina órfã criada pela família $B$.

7. Artuliana não tinha muita simpatia por Maria dos Anjos, a julgar pelo que conta dela: "Dos Anjos vivia com o padrinho Antônio F.; uma vez foi trabalhar para a família de Joaquim B. e nunca queria voltar para a casa do padrinho. Acabou ficando com eles. Antônio F. avisou-os que ela era "muito mal ouvida, muito fugida”. Nos primeiros tempos, fazia tudo o que os outros pediam, depois não ouvia mais ninguém. Obedecia um pouco a Mariana, mas ela e Joaquim podiam falar que dos Anjos nem ligava. Eles não falavam nada porque eram crentes. Às vezes ela resolvia e trabalhava, mas também quando não queria, vivia para as casas dos vizinhos, sem fazer nada. Artuliana logo via que "ela estava com tentação e deixava”. "Quem não vive com crentes não vive com ninguém”. Maria dos Anjos não era boa crente. Levantava calúnia contra eles, dizia para os vizinhos que não davam comida para ela, 
quando era ela mesma que não queria comer. Ela falava que estava doente e tinha mesmo enxugado de corpo "desde que fora viver conosco".

8. Conceição morava com Leonora fazia uma semana mais ou menos: era "visita".

9. Nesse quarto, de cerca de dois metros de comprimento e um metro e meio no máximo de largura, dormiam Joaquim, Mariana, Artuliana e Maria dos Anjos. terrogado por nós sobre as razões que o induziram a pensar que a rapadura tivesse conotações demoníacas, não conseguiu explicá-las, e admitiu que podia ter sido roubada pelo gato e depois deixada no terreiro. Em todo o caso, naquela noite, após as tumultuosas experiências da reunião, depois que Maria dos Anjos fora acusada de ter o diabo no corpo, parece que era suficiente para Geraldo ver a rapadura num lugar fora do comum para atribuir a culpa ao demônio. Ninguém, além disso, achou absurda a afirmação de Geraldo; e tampouco acharam absurdo, logo depois, que Satanás saísse, como afirmou Joaquim, invisível a todos, exceto a ele, da rapadura, para entrar em Eva, filha de Maria. Joaquim começou a bater em Eva para expulsar o demônio até que Artuliana declarou que ele saíra do corpo de Eva; a sua afirmação também foi aceita sem discussão.

Expulso Satanás do corpo de Eva, Conceição ${ }^{8}$, menina de 13 anos, declarou que deviam permanecer todos juntos para rezar a fim de resistir melhor aos ataques do demônio. Várias pessoas foram dormir, mas a maioria reuniu-se na casa de Geraldo A. P., onde Conceição passou a noite profetizando: profetizou que a viagem ao Tabocal seria bem-sucedida, que o mundo acabaria logo, que parentes de Joaquim se converteriam ao Adventismo. Disse, entre outras coisas, que Ana, filha de Manuel, tinha ciúme dela por causa de Serafim, o filho mais moço de dona Maria, e pediu que Ana fosse chamada para pedir-lhe perdão. Joaquim considerou justo o pedido de Conceição e mandou chamar Ana que, acompanhada pelo pai, lhe pediu perdão. Não se pode deixar de pensar que Joaquim estivesse aproveitando de qualquer pretexto para continuar sua guerra fria contra Manuel, o qual evidentemente não gostou de ser chamado no meio da noite para acompanhar a filha a pedir desculpas a uma estranha diante de quase todo o grupo.

Raiava a madrugada quando Joaquim declarou que "o Satanás estava deitado na cama em sua casa"; correu, seguido pelos outros, para casa, entrou no quarto 9 em que Maria dos Anjos dormia e começou a bater na moça. Na confusão um pintinho saiu debaixo da cama. Joaquim disse que era o demônio saído do corpo de Maria dos Anjos, arrastou-a para fora, obrigou-a a ajoelhar-se e depois, todos juntos, "dirigiram a oração".

Antes de prosseguir na narrativa dos acontecimentos dos dias sucessivos, convém sublinhar certos particulares que nos parecem dignos de nota. Pelo que até agora expusemos, parece evidente que são as pessoas relativamente estranhas ao grupo (Joaquim, Artuliana, Conceição e em seguida João B. irmão de Joaquim) que assumem o papel mais ativo nos fatos. In- 
dependentemente da explicação que o estudo dos componentes psicológicos desses indivíduos possa fornecer, convém lembrar que a família B. se achava em pleno processo de assimilação num grupo já formado há tempo. Essa família, como vimos, não alcançara ainda uma posição definitiva no grupo, e essa instabilidade de status pode ter contribuído para criar um certo atrito com várias das pessoas que já lhe pertenciam; poderia, pois, parecer que os membros da família B. se aproveitassem da pretensa presença do demônio para desabafar os seus próprios ressentimentos. A agressividade de Joaquim para com Maria dos Anjos, todavia, não é por ele relacionada a motivos pessoais (cuja existência será confirmada mais tarde), mas antes à presença nela do demônio, em nome de quem (e não, repetimos, em nome dos seus motivos pessoais) Joaquim bate na moça. Como vimos, uma vez que ninguém duvida da existência de Satanás, o comportamento de Joaquim é aceito pelos outros como justo e a designação de "expulsador de Satanás", que lhe é atribuída, tem uma conotação quase honorífica.

A manhã seguinte, quinta-feira $7 \mathrm{de}$ abril, é calma. Por volta do meiodia Joaquim reuniu os que se encontravam na clareira e foi com eles à casa de dona Francisca, que estava doente, a fim de rezar para que recuperasse a saúde. Enquanto rezavam, Maria dos Anjos, de volta da roça, foi ter com eles. Joaquim aproximou-se-lhe "e deu uma mordida no rosto dela. Se o Satanás não tira sangue não sai" disse Joaquim. Logo depois Joaquim bateu pela segunda vez em Eva "mas foi pouca coisa" como ela própria disse. Recomeçaram a rezar e de repente Conceição - como que retomando um jogo interrompido, jogo que na véspera chamara para ela a atenção geral profetizou que na casa de Adão entrara Satanás. Interromperam as orações e "todos foram para lá. Joaquim pegou Josefina (filha de Adão e de Rita) e acordou Durvalina ${ }^{10}$ e trouxe para o terreiro. Bateu Josefina no chão, mussungou (sic) no chão primeiro a Josefina e depois a Durvalina”. Joaquim tinha mandado Zé de Lara ${ }^{11}$ chamar Maria, mulher de Sebastião, para que não ficasse só em casa, agora que Satanás voltara. Maria, com seus dois filhos, Manuel e Josué, dirigiu-se para a casa de Adão; Josué estava no colo de Zé de Lara e, quando chegaram, "Artuliana tirou ele da cacunda de Zé de Lara e deu para o Joaquim para espancar". Terminadas as orações e as bordoadas, foram para casa a fim de preparar-se para a viagem ao Tabocal.

À tarde, Onofre passou pela casa de dona Maria para ver se estavam prontos para a viagem. Joaquim foi ter com ele pouco depois e Onofre começou subitamente a "falar línguas; confessou ele que estava fraco na fé por causa de um casamento que tinha arrumado ${ }^{12}$ mas agora não ia mais casar”. Abraçou
10. Durvalina, sobrinha de Rita, morava há tempo em casa da tia. A mãe de Durvalina é mulher de má fama e é filha de pai desconhecido.

11.Zé de Lara era um dos namorados de Artuliana e queria casarse com ela. Quando ia visitá-la no Catulé ficava na casa dos $\mathrm{B}$.

12. Joaquim não via com bons olhos esse casamento. Ele queria, segundo diziam alguns, que se casasse com uma das suas irmãs. 
13. Provavelmente essa profecia, ou foi atribuída a Onofre depois da sua morte, ou então uma referência vaga a "dois praças" foi, depois de sua morte, interpretada como um ato de clarividência.
Joaquim e os dois caíram por terra "onde ficaram juntinhos como se dormissem”. Quando se levantaram, Onofre profetizou que Pai Joaquim de Água Boa se converteria; que o "irmão Junílio ia cair na fé" durante a viagem, quando se hospedaria numa pensão em que comeria "gordura de porco". Onofre encontrar-se-ia com o "irmão Junílio" na nova terra. Parece que, entre outras coisas, profetizou a queda da Igreja e a chegada de dois policiais ("representei dois praças") ${ }^{13}$ e começou a bater palmas. Depois, terminando as profecias, decidiu que não iriam mais ao Tabocal porque não podiam deixar uma parte do grupo, isto é, as pessoas de idade e as demasiado jovens, as quais ficariam no Catulé, sem ninguém que "tivesse leitura".

A nosso ver, entre os acontecimentos de quinta-feira relatados até aqui, destacam-se dois elementos importantes que talvez valha a pena sublinhar antes de prosseguir na narrativa. O primeiro é o desabafo da agressividade de Joaquim que, visando às crianças, assume um novo aspecto. À nossa pergunta sobre o comportamento usual de Joaquim com referência às crianças, todos foram unânimes em declarar que ele gostava muito delas. "Era tão agarrado com as crianças que até enjoava". Enquanto, pois, na noite anterior, a escolha das pessoas contra as quais se descarregara a agressividade de Joaquim fora motivada por razões mais ou menos evidentes, com o seu ataque às crianças Joaquim parece abandonar uma conduta cujos motivos não lhe podiam ser de todo ignorados para assumir um comportamento "impulsivo" isto é, completamente inconsciente, dominado pela pura agressividade e independente de qualquer motivação pessoal consciente. O segundo, a nosso ver importante, é a conduta de Onofre que, suspendendo a viagem a Tabocal, da qual deveria ser o chefe, perde assim a possibilidade de romper aquela atmosfera criada pela presença do demônio, revelado por Joaquim.

De volta à casa, Onofre informou à mãe que já não se chamava Onofre, mas "Eucride" (sic); parece que no mesmo dia também Joaquim e Geraldo A. P. mudaram de nome. O primeiro disse chamar-se Elias, o segundo, Paulo. Não conseguimos colher material sobre o assunto (Geraldo, o único dos sobreviventes, não se lembra sequer de ter mudado de nome) de modo que não podemos saber que motivos orientaram a escolha da nova apelação. $\mathrm{O}$ fato dessa mudança poderia, contudo, representar um modo inconsciente de fugir à responsabilidade dos próprios atos, ou o desejo de responsabilizar por eles personalidades novas e mais fortes pelas quais os três fossem como que "possuídos" ou inspirados. As ocorrências que seguem parecem sugerir que a primeira hipótese pode explicar melhor o comportamento de Onofre 
enquanto a segunda oferece uma chave mais adequada à compreensão do comportamento dos outros dois.

À noite reuniram-se na casa de Onofre. Terminado o ritual do culto, estavam para recitar as últimas orações quando Joaquim agarrou Maria dos Anjos, fê-la sair de casa e espancou-a. Depois levou-a de novo para dentro e quis que todos lhe pedissem perdão: "Desde quarta-feira Joaquim vinha com este negócio de pedir perdão. Dizia que todos deviam pedir perdão porque podia haver um pecado escondido. Ele pediu perdão de um por um, insistia muito: Perdão em Deus. Pediu perdão uma porção de vezes a Maria dos Anjos”. O único que se recusou foi Manuel S. que respondeu a Joaquim: "Não me amole, não". Joaquim agrediu-o e desta vez expulsou-o da Igreja e ninguém intercedeu em favor do velho. Até aqui repete-se o que sucedera na noite anterior, mas as medidas adotadas por Joaquim são mais drásticas. Manuel antes e Maria dos Anjos depois são definitivamente expulsos; porém, antes da expulsão de Maria dos Anjos, o drama toca Nelcina, uma menina de 5 anos que perdeu a vida. De fato, expulso Manuel, saíram ao terreiro e Conceição recomeçou a profetizar: "Falou que o demônio estava no gato que estava na casa”. Joaquim e mais alguns correram para procurá-lo, e o gato, fugindo, entornou uma lata de querosene. O barulho acordou Nelcina, neta de Cristina e sobrinha de Onofre, que dormia na casa. Joaquim, segundo contam, vendo a menina esticar-se, disse que Satanás entrara nela. "Quando saíram de casa traziam Nelcina, dizendo que estava com Satanás. Pelejaram muito para tirar o demônio". Joaquim batia-lhe dizendo: "Sai Satanás! Sai Satanás!" Mas Satanás não queria sair. Artuliana contou-nos que confirmou a obstinação do demônio porque ouviu a menina, que era gaga, dizer com voz firme que Satanás queria morar com eles. Artuliana foi a única pessoa presente que ouviu a menina falar. "Puseram a menina em pé na soleira da porta, toda enlameada (chovera ininterruptamente naqueles dias) e chorando; João B. irmão de Joaquim, dizia "Olha o Satanás chorando" e continuaram a bater nela. Onofre e Cristina ficaram com dó e falaram que parassem, mas Joaquim e João disseram que Satanás não sentia dó e mandou todo o mundo virar as costas para a menina". Alguns não obedeceram e viram "João pegar a menina pelos pés e bater com a cabeça dela no chão". Quando João ia repetir o gesto Onofre o impediu. "Deixaram a menina deitadinha no terreiro. Conceição disse: O Satanás está lá fazendo fitas para a gente chorar. Ninguém sabia que a menina tinha morrido". Continuaram a rezar para que o demônio saísse do corpo de Nelcina. Enquanto rezavam, Joaquim viu no rosto inchado de Maria dos Anjos o sinal da presença do diabo, e Artuliana 
sustentou o irmão dizendo: "Estou arrepiando toda. É ele! É ele! Joaquim aproximou-se de Maria dos Anjos e começou a tocar "um caroço" que a moça tinha no pescoço. "Apalpou e disse que era Satanás" e perguntou-lhe, como se estivesse falando com o demônio, porque morava com eles. A moça respondeu: "Eu moro aqui porque você disse que quando eu fosse maior você casava comigo". Ao que Joaquim respondeu: "Olha, irmãos, o Satanás falando em casar. E eu que dormi com o Satanás” e confessou ter dormido com o demônio, isto é com Maria dos Anjos, durante cinco noites: "Aí foi que nós vi ( $s i c)$ que ela não era moça donzela". Joaquim ordenou que todos virassem as costas para a moça e orassem por ela. Maria dos Anjos aproveitou a ocasião para fugir. Quando Joaquim percebeu, correu atrás dela com um bastão. De volta, disse que a moça estava possuída por um demônio havia cerca de quinze anos e que nunca mais poderia livrar-se dele.

É interessante notar como o próprio Joaquim revelou uma das razões, se não a mais importante, que motivava o seu comportamento hostil para com Maria dos Anjos. De fato, Joaquim confessou uma ação que em tempos normais custara a Eva e Avelino a expulsão do grupo de crentes. Talvez por isso mesmo Joaquim parece associar as duas moças, encontradas ambas numa situação semelhante, e agride-as uma após outra, por duas vezes, quarta-feira à noite e quinta de manhã. Porém, enquanto Eva e Avelino tinham confessado que haviam cedido aos prazeres da carne, Joaquim não admite o seu pecado, mas conta que foi tentado pelo diabo, incorporado em Maria dos Anjos, e que depois, embora tivesse caído na armadilha, soube reconhecer e expulsar Satanás do grupo. Nem Onofre nem os demais abriram a boca para censurar o comportamento de Joaquim. Este ordenou que todos continuassem a rezar para defender-se dos ataques do demônio, mas Conceição interrompeu as rezas para anunciar que ela tinha trocado de nome: "Meu nome é Jeremias: quem me chamar Conceição será destruído". Outros seguiram o seu exemplo: João B. chamou-se Sem; João A. dos S. passou a João Batista; Adão, a Daniel; Artuliana, a Maria Eunice; Mariana, a Miriam; Eva, a Marta; Serafim, a Daniel etc. Joaquim batia nos ombros dos que não mudavam espontaneamente de nome e insistia e incitava-os dizendo: "Revela, revela!" até anunciarem o novo nome. Depois dessa mudança geral de nomes, Joaquim indicou o céu e anunciou que Jesus desceria para levá-los à "Cidade Celeste de Canãa”. Apontava ora à direita ora à esquerda, dizendo: Ele vem aí. E como os outros nada vissem, acusou-os de pouca fé. Enquanto olhava para o alto Joaquim começou a assoviar, depois parou e disse: "Vocês não sabem que assovio é este". Pediu que o imitassem mas ninguém o conseguiu. 
Ordenou então que fechassem os olhos; quando ele parasse de assoviar deveriam abri-los e ele fecharia os seus. Dado o sinal viram que as nuvens se espalhavam e as estrelas se juntavam para mostrar o lugar onde ficava a Cidade Celeste de Canaã. Ficaram ajoelhados esperando. Ao alvorecer Joaquim disse que não haviam subido ao céu "por causa de um casamento que tinha marcado". Depois aproximou-se de Nelcina e, percebendo que a menina estava morta, anunciou que o demônio a matara. Começou a caminhar em redor do corpo colocando atentamente um pé na frente do outro, batendo as mãos e cantarolando: "Satanás morreu, Satanás morreu!" Três cachorros e dois gatos que se haviam aproximado da menina durante a noite também foram mortos. O corpo da menina, disse Joaquim, devia ser queimado, mas foi deixado onde estava e todos voltaram às suas casas.

Sexta pela manhã, Germana, irmã de Onofre e noiva de Joaquim, rompeu o noivado devido ao que o noivo dissera na véspera ("que nós não ia ir para o céu por causa de um casamento que tinha marcado"). "Se fosse por isso - disse Germana - era melhor desmanchar porque no céu não havia disso. Todos viviam como anjos". Joaquim concordou com ela.

Na mesma manhã Onofre saiu à procura de Geraldo J. que se encontrava, como dissemos, na casa de Onório C. Este porém o informou de que o correligionário, depois de ter esperado algum tempo, saíra para visitar outros grupos: andaria devagar, para que Onofre o pudesse alcançar. Mas Onofre não o procurou: demorou apenas o tempo de contar que o Satanás havia atacado o Catulé e morto uma criança. Durante a volta, Onofre encontrou Manuel S. e disse-lhe que esperava a volta de Geraldo J. para fazer alguma coisa, mas nenhum dos dois tomou a iniciativa de avisar o proprietário da fazenda nem a polícia. Onofre voltou, sim, ao Catulé, mas sentouse debaixo de uma árvore perto de sua casa e se pôs a chorar, "E chorou durante longo tempo".

Antes do retorno de Onofre, cerca do meio-dia, Joaquim e os outros haviam agredido Manuel M., pai de Nelcina. Manuel M. morava perto da lagoa de Santo Aleixo, a meia légua de Catulé, e, como de costume, vinha assistir, em companhia da mulher Isabel, filha de Cristina e meia-irmã de Onofre, e dos filhos, Alfredo de dois anos e Ananias de um, à entrada do sábado. Mal tinha chegado e já Conceição o acusava de "estar cheio de pinga”, o que era pecado. Artuliana, ao contrário, afirmou que Manuel M. não estava bêbado, mas possuído do demônio. Conceição acrescentou que ele era responsável pela morte de sua filha (morte essa que Manuel M. ainda ignorava) "porque era ele que tinha o Satanás no corpo". Artuliana aproxi- 
14. O que faz supor que Zé de Lara tivesse recebido o dom de "enxergar” o demônio. mou-se-lhe e, sempre ativa em agredir as crianças, pegou Ananias, que estava no colo de Manuel, e começou a batê-lo enquanto os homens agrediam o pai. Como ele não reagisse, pensaram que o Satanás, recusando-se a sair do corpo, o houvesse matado. Manuel, portanto, não podia ser tocado. Arrastaram-no para o mato, os pés atados com embira e alguém foi buscar lenha para cremá-lo. Joaquim e João voltaram à clareira e, depois de Manuel M. socaram Josefina. Artuliana acusou-a de estar com Satanás e bateu com o rosto dela no chão. Deram-lhe também umas chicotadas. Até Geraldo A. P. percebeu que Satanás tinha sido exorcisado pois, saindo do corpo da menina, lhe havia queimado o pé. Deram a menina a Zé de Lara para que a levasse perto de Manuel e ordenaram-lhe "que ficasse vigiando para ver se o satanás saía"14.

Depois acusaram Durvalina, uma menina de sete anos. Esta tentou defender-se recitando um trecho da Bíblia que sabia de cor, mas Artuliana disse "Olha Satanás recitando a Bíblia”. Durvalina pegou um pedaço de pau e escreveu algumas letras do alfabeto no chão como se isso pudesse salvá-la. Artuliana disse "Olha Satanás querendo escrever" e a menina foi espancada.

Depois de Durvalina, Artuliana acusou André, um menino de 4 anos, filho de João A. dos S., pegou-o e "o jogou no mandiocal de dona Francisca. Uma folha de arvoredo veio caindo e pousou no menino. Geraldino (Geraldo A. P.) disse que a folha havia sido enviada por Deus para provar que o menino não tinha nada. Geraldino pegou a folha e ficou com ela na mão boa parte do dia”. Depois do episódio de André, Joaquim retomou o tema da ascensão ao céu dizendo que ao entrar do sábado seriam levados ao céu. Ao ouvir a notícia Artuliana "ficou transtornada" e começou a gritar "Vamos para o céu! vamos para o céu!", enquanto Geralda “arrancou para a casa para arrumar a roupa" porque pensou "vamos hoje para o céu e estou assim tão suja". Acalmada a excitação produzida pela notícia, Joaquim ordenou que todos se ajoelhassem "para fazer penitência". Se alguém começava a levantar, "mussungava” (sic) "Para baixo outra vez". Depois começou a se torcer, ajoelhava, pulava e ajoelhava outra vez dizendo que ninguém tinha aquela agilidade e quis que todos o imitassem; ameaçava os que não o faziam, a seu ver, com bastante presteza, dizendo que não ascenderiam ao céu com os demais. Experimentaram longamente esse primeiro salto do qual, no momento oportuno, dependeria a ascensão de cada um; depois Joaquim interrompeu-se e disse a João que juntos deviam dirigir-se além do rio Urupuca porque também João, como Onofre e Joaquim, devia "desmanchar um casamento que tinha tratado". 
Partidos ambos, Geraldo A. P. e Rita foram para onde tinham deixado Zé de Lara que, como sabemos, havia sido incumbido de guardar Manuel M. Geraldo A. P. ordenou a Zé de Lara que desamarrasse Manuel, Rita retomou a filha ${ }^{15}$ e acompanhada por Geraldo A. P. e por Zé de Lara, voltou ao Catulé. Manuel M. passou o resto da noite escondido num mandiocal e no dia seguinte foi para Malacacheta, onde chegou sábado cedinho, e onde deu parte à polícia (a qual, entretanto, só se resolveu a verificar o que havia de verdadeiro na descrição de Manuel no domingo depois do almoço).

Entrementes, as pessoas do Catulé estavam em preparativos para ascender ao céu. Adão, por exemplo, pôs-se à procura de Maria dos Anjos a quem devia vinte cruzeiros, porque temia que se não pagasse a dívida em tempo não poderia subir ao céu. Adão foi até a casa de José $P$. onde julgava que Maria dos Anjos estivesse refugiada, porém, não a encontrando, voltou ao Catulé, depois de contar o ocorrido a José P.

A notícia, pois, dos acontecimentos do Catulé, espalhara-se por um raio bastante extenso, mas nenhuma das pessoas informadas e estranhas ao grupo achou necessário chamar para os fatos a atenção quer das autoridades de Malacacheta, quer do fazendeiro. $\mathrm{O}$ que pode indicar a falta de familiaridade, e talvez de confiança, que os roceiros da zona têm em relação às autoridades. No que diz respeito ao grupo, ao contrário, o fato de terem voltado ao Catulé todos os que se haviam afastado, por motivos diversos indica como era viva neles a fé na ascensão ao céu, e como todos acreditavam nas palavras de Joaquim.

De volta à casa, Adão, sentindo-se cansado, quis ir dormir, mas antes sacudiu por precaução a esteira. Enquanto a sacudia, viu um galo que "o cumprimentou", e certo da presença do demônio no animal, "correu para junto dos outros".

Joaquim e João, por seu lado, visto que não teriam tempo de ir e voltar do Urupuca sem "estragar o sábado", tinham renunciado à viagem e a meio caminho haviam decidido voltar. Assim que chegaram ao Catulé, cuidaram de queimar o corpo de Nelcina com os cadáveres dos três cães e dos dois gatos mortos na véspera. Para não tocar o corpo da menina (pois estava claro que o diabo não tinha saído) ergueram os pés com um pedaço de pau, passaram um laço de embira em volta das pernas e arrastaram o corpo até a fogueira que tinham preparado e igualmente arrastaram os animais para cremá-los. Depois reuniram-se todos em casa de Onofre. Ninguém se lembrou mais da promessa de subir ao céu porque na mesma noite começaram as bordoadas "para apurar a Igreja de Deus". Sexta-feira à noite estabelece-se
15. Rita pegou a filha e levou-a para casa. Lavou o rosto da menina que estava todo inchado e deu-lhe comida, mas não o peito porque tinha medo - "Joaquim tinha dito que não podia dar o peito a Satanás". 
o nexo entre as bordoadas e ascensão ao céu: de fato, até sexta-feira de tarde alguns membros do grupo (Manuel M., Josefina, Durvalina e André) são esbordoados para que se libertem do demônio, mas sexta-feira à noite já não é esse o único fim: agora o grupo deve purificar-se para que se dê a ascensão, e na tentativa de purificar a Igreja de Deus decorre a noite de sexta-feira. Durvalina, Isabel, Cristina, Francisca, Rita, Ana Erminda, José Luiz, Alfredo, Adão, Serafim, Alaíde, Zani e André foram espancados. Vale a pena relatar alguns dos depoimentos orais dos agredidos. "Na sexta-feira bateram nela (Francisca), em Alaíde (sua neta e filha de Geralda) e em André (seu neto e filho de João A. dos S.). Alaíde estava na cacunda ( $s i c$ ) de Geralda, Artuliana veio, rodeou e disse "olhe os olhos dela", Geralda disse que a menina não tinha nada que a deixassem sossegada. Artuliana disse que tinha sim, os olhos dela mostravam, estava toda cinzenta. Pegaram a menina e deitaram de bruços no terreiro. Depois pegaram ela mesma (Francisca), deitaram-na ao lado de Alaíde e apertavam a garganta e falavam "Lança, lança o Satanás”. Ela fazia forças mas não tinha ânsias, não conseguia lançar. Não sentia o Satanás dentro de si, "mas é uma coisa invisível, ninguém pode ver, pensei que podia estar com ele". Com o esforço que fazia ficou com sede e pediu água. Onofre foi buscar para ela - ele já estava pervertido, mas nisso foi bom. Disse a Onofre: "Irmão, me dá um pouco d'água, quem sabe eu lanço". Mas continuou sem lançar, eles sempre apertando a garganta. Ficou com sede novamente. Onofre mandou que fosse beber no rio, pegou as duas crianças e fugiu para a casa de Manuel S. Depois não podia voltar mais porque João B. tinha dito que ela estava "cortada”. O medo que sentia não era de Joaquim ou dos outros, mas de Satanás. Ninguém tinha coragem de ficar sozinho de medo do Satanás, mas de dia ninguém tinha medo. Ficou na casa de Geraldo R. dos S. até a madrugada e depois, com Alaíde e André, foi para a casa de Manuel S. De manhã voltou para buscar comida para as crianças, João B. pegou-a e bateu-lhe muito. Ela falava para ele que aquilo não estava certo, que a Bíblia não mandava bater. Ele respondia: "Cala senão te mato. Cala, cala” e ela calou.

Rita conta que Joaquim e Artuliana pegaram sua filha Josefina bateram pela terceira vez; além de espancá-la, Joaquim mordeu-a; depois bateram nela, Rita, mas ela fugiu para a casa de Manuel S. e só na manhã seguinte voltou para buscar a filha "quando levei três pancadas de João B.” Quase todos os que foram surrados durante a noite refugiaram-se na casa de Manuel S. ou numa casa a poucos passos da fazenda. Pela madrugada Joaquim disse: "Os filhos de Caim fugiram mas os filhos de Abel ficaram". 
Sábado, 9 de abril, de manhã cedo, encaminharam-se em pequenos grupos para a casa da oração.

Joaquim foi um dos últimos a sair, seguido de João que, montado a cavalo, ia devagar devido ao mato espesso. De repente, Joaquim gritou-lhe que não ficasse atrás. João largou o animal e correram para alcançar os outros. Alcançaram-nos no meio do caminho e gritaram que os esperassem.

Joaquim colocou todos em fila, tendo o cuidado de pôr na frente os que estavam por último. Com um pedaço de pau traçou um círculo ao redor dos pés de cada um e ordenou que ficassem imóveis, sem olhar para trás, senão veriam o demônio.

Então Joaquim chamou: "Pai, ó meu Pai Santo", e anunciou: "Eu sou Jesus, filho de Deus Altíssimo"; indicando Onofre, disse: "Ele é o Cristo". Em seguida começou a preparar ativamente a ascensão do grupo. Pegou o lenço e, enquanto "varria" os pecados de cada um, jogava fora tudo o que era "lixo" porque iam subir para a Cidade Celeste de Canaã. Pedindo muitas desculpas, jogou fora enfeites, grampos, lenços, sapatos, paletós, chapéus. Os homens ficaram de calça e camisa, as mulheres apenas com o vestido. Jogou fora também todo o dinheiro que tinham e a carteira de Onofre com mais de mil cruzeiros. Rosa, filha de Maria, conta a cena com muitos pormenores: "Primeiro pegou a moeda que Rosa levava para a coleta e jogou-a no chão, dizendo que era lixo. Depois mandou Onofre apanhála; quando ele ia pegando, com ar de caçoada, falou-lhe: "Mas irmão, não vê que é lixo?" e chutou a moeda. Depois fez a mesma coisa com a carteira de Onofre, caçoando com ele cada vez que ia buscá-la. Onofre falou-lhe que levava mil cruzeiros que devia a Manuel S. e pôde reavê-la, mas daí Joaquim mandou que tirasse o paletó e o jogasse com a carteira no mato".

Ainda estavam no mesmo lugar quando Geraldo R. dos S., que os havia esperado por muito tempo na casa de oração, voltou com dois crentes para ver o que estava acontecendo. Joaquim pediu que entrassem na fila e perguntou a Geraldo R. dos S. se conhecia o seu nome. Este respondeu: "O seu nome é Joaquim". Joaquim foi até Conceição, pegou-a no colo e repetiu-lhe a mesma pergunta, acrescentando: "Revela o meu verdadeiro nome". Conceição respondeu: "O seu nome é Jesus". Largando a menina, aproximou-se de Maria, mulher de Sebastião, perguntou-lhe se estava disposta a pagar qualquer preço pela salvação. Maria aceitou, e Joaquim ordenou-lhe que jogasse na mata o filho que trazia nos braços. Maria relutou em obedecer: era um preço muito alto. Joaquim pegou a criança e atirou-a para longe. Onofre interveio, dizendo que aquilo não estava certo, mas Joaquim 
respondeu-lhe que dali por diante era ele que devia mandar e não Onofre, "que Onofre devia ficar sob o domínio dele". Joaquim foi até Geraldo R. dos S., e pediu-lhe que jogasse fora o paletó; Geraldo obedeceu. Joaquim pediu-lhe então que jogasse fora o filho que tinha no colo. Geraldo recusou-se e voltou para o Catulé.

Se de um lado Joaquim requer obediência, de outro, oferece também prova do seu poder fazendo milagres, e curando os que se diziam enfermos. Fazia muito tempo que estavam parados, esperando. Algumas mulheres queixaram-se de sede e cansaço. Artuliana, exausta, caiu. Joaquim cuspiu na boca de Artuliana, e esta se levantou. Cuspiu também na boca da Conceição, que tinha sede, e a sede milagrosamente desapareceu. Passou saliva nas pernas inchadas de outras mulheres e o cansaço sumiu. Passou saliva na mão de Geraldino "que tinha sido picado por uma barata" e a dor desapareceu.

Depois de tais milagres, Joaquim disse que não iam para o céu porque ele tinha um pecado oculto, "mas não falou qual era". Começou a assoviar; era o mesmo assovio, aquele que não podia ser imitado. Maria pegou o filho, chamou Sebastião para que fossem embora mas ele não quis ir. Ela pegou Manuel que estava com ele e voltou para casa com as duas crianças. Os dois crentes que tinham vindo com Geraldo R. dos S. foram-se embora e os outros marcharam até a casa da oração, ao ritmo do assovio.

Lá chegando, Artuliana quis pedir água na casa de José P., mas Joaquim não permitiu. Chamou José para o terreiro e perguntou-lhe onde estavam os crentes do rio Urupuca. Ele respondeu que haviam ficado esperando desde as 11 horas da manhã e, sendo já quatro da tarde, há muito tinham ido embora. Joaquim acusou-o de ter afastado os crentes de propósito. José foi agarrado pelas orelhas. Começaram a espancá-lo; obrigaram a mulher a deitar-se no chão, e apontavam para a veia jugular que palpitava, dizendo: "Olha satanás tomando força". Bateram também nos dois meninos, mas desistiram quando eles "vomitaram Satanás". Agora que estavam purificados, deviam ficar com o grupo; José, ao contrário, dificilmente podia ser salvo, porque tinha "sete satanases batizados na barriga". Joaquim ordenoulhe que fosse até a chapada; se não vomitasse os satanases no caminho, morreria lá mesmo.

José fugiu com a mulher, deixando os filhos, e foi para Malacacheta onde chegou domingo de manhã cedo e deu parte à polícia.

Estava escuro quando os moradores do Catulé voltaram para casa. Enquanto jantavam, ouviram chorar Pedro, o filho menor de Geraldo R. dos S. Comentou Joaquim: "Precisamos matar esse satanasinho". Acabou de 
comer e foi para a casa de Geraldo - os outros correram para ver. Artuliana acusou Pedro de estar possuído do demônio e ordenou a Geraldo R. dos S. que o estendesse por terra. Geraldo obedeceu e Joaquim pisou com força "em cima dele". Satanás saiu do menino morto, disse Artuliana, passou por entre as suas pernas e "pulou" no filho de Maria, o mesmo que Joaquim havia atirado ao mato e que a mãe fora buscar. Joaquim agarrou a criança e estrangulou- ${ }^{16}$. Artuliana declarou que todos os filhos de pessoas "casadas no padre" tinham Satanás no corpo. Olhou para João, filho maior de Geraldo R. dos S., e disse que o menino estava inchado, os olhos estavam ficando vermelhos e "cheirava a catinga". O menino, que era muito acanhado, baixou a vista e correu. Joaquim pegou um machado, foi atrás dele e matou-o.

Ninguém tinha podido dormir até ali, Joaquim não deixava. Depois que matou as crianças, Joaquim sossegou e foi para casa dormir. Os outros também foram dormir: "parece que ele queria aquilo desde o começo quando matou sossegou".

Domingo pela manhã, Adão foi chamar Joaquim que tinha dormido em casa de Onofre, para dizer-lhe que a sua casa estava infectada. Adão, que desde o dia em que sua mulher Rita fora "cortada", não havia mais usado a casa ${ }^{17}$, mas tinha ido morar com a mãe, não soube explicar-nos o que lhe havia sugerido semelhante idéia. Joaquim acompanhou-o e decidiu que a casa de Adão "estava com Satanás” e que era preciso queimá-la. Passaram pela casa de Geraldo A. P. onde Joaquim, vendo o paletó de Manuel S., jogou-o no terreiro e ordenou que o queimassem. "Iam cheirando os trens e dizendo que fediam a Satanás". Entraram na casa de Cristina e começaram a atirar fora lençóis e a quebrar "as vasilhas" porque tudo "fedia a Satanás” e tinha de ser purificado pelo fogo. De repente, os que estavam em casa de Cristina viram Joaquim sair da cozinha e entrar no quarto de Onofre onde, sentando-se à beira da cama, com as costas contra o muro, começou a masturbar-se. Quis que todos vissem o que era o pecado. Onofre, que estava presente, "ficou quietinho com a mão nos olhos". Joaquim levantouse e, pondo uma mão nos olhos e a outra nos órgãos genitais, saiu para o terreiro andando na ponta dos pés. Lá masturbou-se diante dos que tinham ficado do lado de fora repetindo que todos deviam ver o que era o pecado. Entrando de novo em casa, confessou que se masturbava "em louvor de Germana, mas era pecado fazer do homem mulher e da mulher homem, por isso estava perdido". Perguntou a Germana se ela também era dada às mesmas práticas. Germana confessou que o fazia pensando nele. Joaquim
16.É interessante seguir os movimentos de Maria desde o momento em que, acompanhada dos filhos, volta para casa, até o momento descrito. Vamos citá-los na íntegra: "Maria pegou Manuel, que estava com ele, e voltou para casa com as duas crianças. Em casa encontrou Cristina, que havia sido expulsa na noite anterior e que voltara aproveitando a ausência dos outros. Cristina voltou para a casa de ManuelS. e levou Manuel consigo. Maria dormiu com o outro menino. Acordou com Manuel S. que tinha vindo buscála. Não quis ir porque Sebastião não tinha voltado e estava ainda com muito sono. Dormiu outra vez e acordou com o choro do filho de Geraldo R. dos S., que também voltara. Foi até lá, ficou com ele um pouco, depois voltou para casa. Estava escuro quando os outros voltaram. Estavam jantando quando ouviu barulho na casa de Geraldo. Foi com o menino para lá. Quando chegou, já tinham matado o filho de Geraldo".

17. Por ocasião de nossa primeira e segunda 
visita, a casa já era habitada, mas usada como depósito para a colheita de milho. Adão continuava a viver, com a família, em casa da mãe e com o tempo pretendia construir uma nova casa. Nunca mais usaria a velha para morar. empurrou Germana contra o muro e chegou-se a ela. "Germana enfiou todo o vestido entre as pernas e pôs as mãos em cima”. Joaquim abraçou-a fingindo uma relação sexual. "Isso - disse Joaquim - apagaria um pouco do pecado, mas não tudo" e avisou Germana que depois do abraço cada qual "cairia para um lado" querendo dizer que se deixariam para sempre. Alguns ouviram Joaquim ordenar a Germana que se punisse com "um sabugo". Essa cena parece que fazia parte de uma confissão geral dos pecados durante a qual João B. declarou a Germana que desejara casar-se com ela. Depois desta confissão Joaquim disse que todos deviam tomar um banho de purificação; deviam despir-se e cobrir-se como pudessem com pedaços de pano que Joaquim tinha em casa e que foi buscar. Poderiam pôr as suas roupas somente depois do banho e depois de lavá-los com cuidado. Quando Joaquim viu que os pedaços de pano não podiam chegar para todos, começou a arrancar os botôes das camisas e das calças dos homens para obrigá-los a ficar nus e arrancou também o vestido das mulheres que lhe pareciam relutantes. Eva estava para tomar banho quando Joaquim a deteve lhe disse "que precisava dar graça no sabão". Eva convidou-o a ir com ela porque "ela não tinha malícia". Joaquim disse que era isso mesmo. "Um menino quando nasce não traz roupa. Traz vergonha? Traz malícia? Ninguém precisava ter vergonha, era para todos tomarem banho juntos. Não precisava ter vergonha porque estavam agora no Jardim do Éden”. Depois lavou Eva "com sabão preto e sabonete" e começou a espirrar água nos outros dizendo: "Esta força não é minha, é a força de Jesus". A água da cacimba turvou-se e todos ficaram sujos de lama. Joaquim disse que era preciso esperar que a água voltasse à limpidez e encaminharam-se ao terreiro de Onofre.

Joaquim pousou a sua Bíblia no meio do terreiro e espalhou milho ao redor; depois matou as galinhas e os pintinhos que não se aproximavam para comer. Mostrou a Bíblia também às galinhas, cães e gatos, matando a pauladas os animais que, assustados, fugiam. Quando a água ficou de novo límpida, voltaram à poça. Joaquim começou por lavar Maria, filha de Francisca, e parece que, durante o banho, "casou-a” com João, seu irmão. Lavou os dois filhos de José P. e em seguida Geralda, mulher de Geraldo R. dos S. A própria Geralda contou-nos que, antes do banho, ele "tirou-lhe o leite que era para o satanasinho que ele havia matado à noite anterior." Depois ordenou à sua irmã Mariana que continuasse e se preparou para lavar Jacinta. Interrompeu-se e começou a acariciar o seio de Rosa, filha de Maria, uma mocinha de 16 anos, dizendo: "Vê se uma menininha como Rosa ia deixar que um rapaz bulisse no peitinho dela. Mas eu pego e ela não faz 
nada". Comentou que não era verdade que "a moça que não é donzela tem seios caídos” porque Maria, mulher de Sebastião, "já tinha dois filhos e tinha ainda os seios empinados". Continuou a lavar os outros mas em certa altura sentiu em si próprio o cheiro de Satanás. O cheiro disse, provinha dos seus dentes de ouro. Chamou João B. e pediu-lhe que o ajudasse a arrancálos. João pegou numa faca afiada e destacou os dentes de ouro. Joaquim começou a perder muito sangue, mas o cheiro passou. Joaquim estava lavando Zé de Lara quando chegou a polícia "que deu voz de prisão". Todos procuraram esconder-se nas moitas menos Joaquim e Onofre que, nus, foram ao encontro dos guardas dizendo: "Nós somos de paz". Porém os guardas dispararam. Onofre caiu morto, enquanto Joaquim e Geraldo A. P. ficaram feridos, o último levemente. Joaquim rolou até a poça e ordenou à sua irmã, mulher grácil e, naquele momento, aterrorizada, que tirasse a arma das mãos de um dos guardas. Mariana tentou obedecer, o soldado deu-lhe na cabeça com o cabo da espingarda. Mariana desmaiou. Os outros vestiram-se às pressas. Levantaram o corpo de Onofre e pousaram-no no terreiro da sua casa, depois, sustentando Joaquim pelas axilas, levaram-no para perto de Onofre. Joaquim pediu para morrer com a palavra de Deus na boca. Alguém arrancou duas páginas da Bíblia e pôs uma na boca de Joaquim e a outra na de Onofre. Joaquim pediu um pouco de água, engoliu a página e logo depois morreu. Os que o rodearam disseram, "não está morto, está dormindo".

Os dois guardas passaram a noite no Catulé. Ninguém dormiu. João B., durante a noite, acusou o filho de José P. de estar possuído do demônio e tentou atirá-lo na fogueira que haviam feito. Os guardas não o deixaram. $\mathrm{Na}$ manhã seguinte chegaram mais dois policiais e o grupo seguiu-os a Malacacheta: "foi na cadeia - disseram-nos - que nos acordou (sic)".

\section{0 grupo e seus problemas socioeconômicos}

Antes de passar a interpretar o material recolhido durante as nossas visitas a Catulé, devemos avisar os leitores que este estudo não tem a pretensão de "explicar os motivos" que determinaram os acontecimentos narrados.

Traduzida em termos antropológicos, a expressão "explicar os motivos" significaria explanar a função social de um aspecto particular da cultura analisada. No nosso caso, porém, o estudo - referente à cultura do grupo em questão - não esclareceria os acontecimentos, pois eles revestem, aos pró- 
18. Tarefa esta que nos foi grandemente facilitada pelo estudo da tese do Prof. Antonio Candido de Mello e Sousa Os parceiros do Rio Bonito: estudo sobre a crise nos meios de subsistência do caipira paulista, tese de doutorado elaborada junto à Cadeira de Sociologia II, São Paulo, 1954.

19.IBGE - Conselho Nacional de Estatística - Serviço Nacional de Recenseamento Série Regional, vol. XXI, tomo 1, Estado de Minas Gerais, Censo Demográfico, Rio de Janeiro, 1954. prios olhos dos membros que constituíam o grupo, um caráter excepcional. Não nos pareceu, pois, oportuno descrever o grupo em termos puramente etnológicos - isto é, examinando todos os aspectos da sua cultura - uma vez que a expulsão do demônio do corpo dos "possessos" não constitui um ritual comumente praticado pelo grupo, cuja função possa ser esclarecida pelo estudo do contexto.

Pelo mesmo motivo, o Adventismo da Promessa, religião acusada de ter provocado as ocorrências, não pode ser considerada responsável, porque, embora admita a possibilidade da possessão diabólica, o seu ritual não pratica as formas de exorcismo usadas em Catulé.

Nem se pode afirmar que a difusão de tal religião em tal ambiente cultural explique o que ocorreu em Catulé durante a Semana Santa de 1955; seja porque, embora difundindo-se por grupos partícipes da mesma cultura, a mesma religião não provoca inevitavelmente resultados semelhantes, seja porque é suficiente ler o relato dos fatos para verificar que alguns fatores de caráter pessoal - por exemplo os problemas sexuais em Joaquim - tiveram uma importância relevante.

Portanto, o estudo da cultura e da religião desse grupo não só deixaria de explicar, como dissemos, os acontecimentos, mas nem sequer forneceria qualquer dado sobre os "tempos" em que se desenrolaram. E para o grupo de Catulé eram tempos críticos pois, destruído o isolamento em que vivia, veio gradativamente a faltar o equilíbrio entre a natureza do lugar e as técnicas de que dispunha o homem para afrontá-la. Pareceu-nos, por conseguinte, necessário determinar nesta introdução qual era, ou melhor, como se estabelecera tal equilíbrio ${ }^{18}$ e quais as razões que lhe causaram a ruptura. O fim, pois, deste artigo, é sublinhar a existência de um conjunto de fatores que foram favoráveis, se não determinantes, ao desenrolar dos acontecimentos no grupo que ora passamos a descrever.

O município de Malacacheta, pertencente à comarca de Teófilo Ottoni, cobre uma área de $2.102 \mathrm{~km}^{2}$ e tem uma população de 33.1064 habitantes $^{19}$; as suas principais atividades econômicas são a agricultura e a criação de gado. A cidade de Malacacheta, chamada pelos habitantes da zona rural "o comércio" ou "a rua”, é sede do município e centro comercial da região. A fazenda de São João da Mata, ou "fazenda Itatiaia", distante da cidade 21 quilômetros que podem ser vencidos a pé ou a cavalo. A fazenda cobre uma área de 320 alqueires; a terra, propícia tanto à criação de gado como a várias culturas - cana de açúcar, café, arroz, milho, feijão, mandioca e batatas - é 
cultivada por meeiros. Vivem muito espalhados pela propriedade. Ocasionalmente, porém, um número limitado de famílias tem oportunidade de se reunir. A meia légua da sede da fazenda encontra-se um desses agrupamentos no lugar denominado Catulé, clareira de cinco alqueires aberta na mata. Em abril do ano de 1955 dez famílias habitavam o local. As mais antigas haviam-se mudado para o Catulé três anos antes. Nos anos sucessivos, chegaram outras.

Essas famílias, com uma exceção, estão ligadas entre si por laços mais ou menos estreitos de parentesco (ver Diagrama, p. 351), portanto, para maior clareza, parte do material colhido será exposto sob forma de história de cada família.

MANUEL S. - nasceu em Poté em 1890 e lá viveu até 1917 lavrando a terra do pai que era "arranchado" ${ }^{20}$. Quando o pai vendeu a terra, poucos anos antes de morrer, Manuel, que se casara em 1916, deixou com a mulher o lugar e transferiu-se para Palmital, município de Malacacheta, nas terras incluídas no triângulo formado pela confluência do rio Urupuca com o rio Jacutinga, "onde ainda não tinha ninguém". "Abri a mata de picada de facão desde Santa Cruz e tirei uma posse". Por volta de 1920 a mulher morreu e, meses depois, Manuel tornou a casar. A segunda mulher chamava-se Maria e era filha de um arranchado. Morto o sogro, Manuel pagou as dívidas por este contraídas num armazém de Malacacheta e, por morte da segunda esposa, ficou dono da terra. Por volta de 1925 casou-se pela terceira vez, com Ana R. dos S. "natural de Setubinha"; o matrimônio durou dezoito anos. Da primeira união Manuel tivera dois filhos e um da segunda, todos mortos na primeira infância; dos filhos do terceiro leito, Maria e Leonora (nascidas em Palmital respectivamente em 1930 e em 1934), vivem ainda, um terceiro filho morreu "miudinho".

Em 1943, tendo Ana morrido, Manuel contraiu núpcias pela quarta vez, com Hermínia T. dos S., sua mulher atual, e filha do terceiro marido de Cristina G. S. O primeiro filho nascido desse matrimônio morreu em 1944. No ano seguinte nasceu Ana (Palmital), que ainda vive.

Em 1945 Manuel perdeu a terra por causa dos novos "extremantes" que, para obrigá-lo a vender, lhe invadiam as plantaçôes com o seu gado; não tendo dinheiro para cercar com farpado os seus trinta alqueires, Manuel foi forçado a vender. Narra que, embora tivesse pago os impostos por muitos anos sobre trinta alqueires, no cadastro de Malacacheta constava que a sua posse não ia além de três. Foi inútil mostrar os recibos das taxas
20.A expressão "arranchado" é localmente usada para indicar uma pessoa que possui terra própria, ou seja, "estabelecida em terra do estado da qual pode fazer lançamento". 
21. "O agregado, como se sabe, distingue-se do posseiro porque tem permissão do proprietário para morar e lavrar a terra, sem qualquer paga, salvo alguma prestação eventual de serviço" (Antonio Candido de Mello e Sousa, op. cit., cap. 1, p. 35). Mas na zona visitada esse termo é usado para indicar o lavrador que, não possuindo terra própria, recebe do fazendeiro para quem trabalha um pedaço de terra da fazenda para cultivar por conta própria; ou então indica o lavrador que aluga um pedaço de terra do fazendeiro. O termo "agregado" é usado indiferentemente para indicar também o "parceiro" que, como veremos, tem direitos e deveres totalmente diversos. pagas sobre trinta alqueires de terra: o comprador pagou-lhe, fiado, somente três alqueires.

Manuel deixou Palmital e foi a Urupuca onde tirou uma posse de três alqueires. "Mas tive aborrecimento com o gado e precisei mudar-me. Tirei outra posse de outra mata, sempre à beira de Urupuca, mas o vizinho fazia a vida lançando gado nas roças dos outros" e decidiu que "lugar para mim é bestagem".

Em 1948 começou a trabalhar na qualidade de agregado ${ }^{21}$ para J. A. de Q. nas terras que este possuía à beira do rio Urupuca. Depois de uns dois anos J. A. de Q. "tirou-me para mais arriba”. Aí construiu uma casa cômoda para a família e para sua filha Maria, que se casara. Depois de uns dois anos o dono vendeu essa parte da fazenda a M. C. e ofereceu a Manuel a possibilidade de transferir-se para Catulé. Manuel aceitou.

FRANCISCA DOS S. - "natural de Norete", nasceu por volta de 1903, em Ribeirão Norete. O pai tinha uma posse em Jacutinga que, por morte sua, em 1925, os filhos perderam "quando um J. G. disse que o pai lhe devia dinheiro e tomou o lugar". Francisca casara-se um ano antes, aos 21 anos, com Antônio R. dos S., "natural de Setubinha”, irmão da terceira mulher de Manuel S. Antônio tinha uma propriedade de cinco alqueires entre Jacutinga e Palmital. Lá a família morou até a sua morte e lá nasceram os filhos, cinco ao todo. Os dois primeiros morreram, ficaram João (nascido em 1927), Geralda (nascida em 1931) e Maria (nascida em 1934). Morto Antônio em 1934, Francisca vendeu a terra "porque tinham prejuízo de criação" e passaram para a fazenda de J. A. de Q. perto de Manuel, cuja sorte seguiram quando este, obrigado a deixar Urupuca, se deslocou para Catulé.

MARIA A. P. - irmã de Francisca, nasceu em 1915 mais ou menos, em Norete; por morte do pai foi viver com Francisca e com ela ficou até o dia em que, em 1929, se casou com Abrão P. B. Foi testemunha de Maria o marido de Francisca, o de Abrão foi Manuel S. Abrão já trabalhava para o "padrinho", Manuel S., e continuou a trabalhar com ele até que conseguiu obter uma posse entre Jacutinga e Palmital, posse essa que ele depois negociou por outra à beira do rio Urupuca. Por morte de um vizinho, porém, surgiu uma questão de divisa, e os herdeiros reivindicaram uma parte da terra de Abrão. "Então ele [Abrão] esquentou a cabeça do lugar e vendeu tudo por menos de 1.400 cruzeiros; eram mais de dez alqueires. Com o dinheiro da venda Abrão comprou dois alqueires na outra margem do rio Urupuca, e, mais 
tarde, vendeu-os a M. C. Trabalhou como agregado na fazenda deste último "mas lá soltavam criação nas roças deles". Deixou M. C. por um novo patrão e quando este vendeu a fazenda, Abrão mudou-se com a família para a de J. A. de Q. onde, em 1943, morreu. Maria e os filhos (Adão, Geraldo, Eva, Rosa e Serafim) "esquentaram a cabeça do lugar" por causa da morte do pai e mudaram-se perto da casa de Manuel S., sempre na fazenda de J. A. de Q. Em 1951, Geraldo emigrou para o Estado de S. Paulo onde ficou um ano pois, em 1952, quando J. A. de Q. vendeu as terras perto do rio Urupuca, onde moravam, Maria e os filhos (Eva, Rosa e Serafim) transferiram-se com Manuel Soares para Catulé. Geraldo precedeu-os; Adão, que casara e morara com os sogros, seguiu-os depois de pouco tempo.

CRISTINA G. S. - nasceu em São João por volta de 1905. Casou-se três vezes. O primeiro marido chamava-se Lino (esqueceu-se do sobrenome), era "arranchado" e, embora a terra fosse pouca, "dava para viver". Depois de uns dois anos de casamento Lino morreu e a terra passou para os seus irmãos porque, para efeitos civis, o casamento não tinha valor (parece que haviam casado na igreja apenas). Alguns meses depois, em 1924, Cristina uniu-se a João S., irmão de Manuel, que era casado mas não vivia com a mulher. Também João S. era "arranchado", mas ao morrer, o que ocorreu em 1928, depois de quatro anos de convivência, a propriedade passou para a mulher legítima. Cristina casou-se de novo quase em seguida com João T. dos S. com o qual viveu 16 anos (1928-1944) e que, ao morrer, a deixou sem terra. "Tive ao todo onze filhos" diz Cristina, "dos quais sete morreram pequenos. Não me lembro, dos que morreram pequenos, quantos eram de um, quantos de outro marido". Dos quatro filhos que lhe restaram, Jacinto e Isabela eram do segundo marido, Onofre e Germana do terceiro. Por volta de 1946, Jacinto emigrou para o Estado de S. Paulo para trabalhar nos campos de algodão de Presidente Prudente. No ano seguinte, Cristina, Onofre e Germana seguiram-no, enquanto Isabela, que se casara, ficou. Viveram em São Paulo cerca de um ano; quando voltaram, Jacinto morreu. Onofre deixou a mãe e a irmã com Manuel S. e voltou para Presidente Prudente. Depois de três anos, em 1951, foi buscá-las e levou-as de novo a Presidente Prudente, onde moraram cerca de um ano, até o momento em que o grupo de Catulé escreveu a Onofre rogando-lhe que voltasse para orientar "os crentes" na fé que havia começado a pregar por ocasião da sua última visita ao grupo. 
GERALDO R. DOS S. - filho de José João R. dos S., irmão de Ana, terceira mulher de Manuel S. e também cunhado de dona Francisca, nasceu em Palmital em 1924. Órfão aos dez anos, foi viver com o "padrinho” Manuel S. Quando este perdeu a terra em Palmital, Geraldo (que se casara aos 14 anos com a irmã de Jacinta, mulher de João de Francisca) e a mulher se uniram a outro tio que era arranchado. Quando, em 1948, o tio partiu para São Paulo, Geraldo "mudou-se, então, para o lugar de J. A. de Q., junto a Manuel S., até que J. A. de Q. vendeu aquelas terras e se mudou para o Catulé”.

Depois da morte da primeira mulher uniu-se a Geralda; com a qual não se casou nem no civil nem no religioso. Geraldo teve seis filhos com a mulher, três dos quais morreram de morte natural enquanto outro foi morto nos últimos acontecimentos da Semana Santa, bem como o caçula tido com Geralda.

SEBASTIĀO M. DOS s. - filho de Lourenço M. dos S. e de Calú S. R., nasceu em Ribeirão, perto de Poté, em 1927. Quando Sebastião nasceu, a família "morava na roça, perto de Poté". Quando tinha mais ou menos três anos, a família mudou-se para a cidade de Poté, onde o pai trabalhava na caieira (era queimador de cal) e na roça também. A mãe "lavava roupa para fora".

Por volta de 1937 o pai morreu deixando cinco filhos, três rapazes, Antônio, José e Sebastião, e duas moças, Geralda e Conceição; Sebastião era o menor.

Os dois filhos maiores, Antônio e José, trabalhavam em Coió, um lugarejo perto de Santa Cruz, pelo que, por morte do pai, o resto da família foi ter com eles. Chegando em Coió, Sebastião começou a trabalhar para um fazendeiro. Sua tarefa consistia em tratar do gado e trabalhar no sítio. Trabalhava "a troco de roupa". "Saí depois de dois anos para ajudar a mãe, e o patrão me deu um poldro de presente”. Em seguida, a família deixou Coió e transferiu-se para Palmital "porque a terra lá tinha mata e era melhor para quem quisesse trabalhar de verdade". Os irmãos casaram-se (Antônio casou-se com Geralda, filha de Francisca) mas, continuaram a viver perto "porque a gentinha da gente é pra ficar junto". Quando uma das irmãs, Geralda, que nesse ínterim se casara, morreu, a mãe foi morar com o genro "para tomar conta das crianças" tanto mais quanto a outra irmã, Conceição, "perdeu-se e foi para São Paulo com um homem". Sebastião, ficando sozinho, começou a trabalhar para Manuel S., "agregado de J. A. de Q." Algum tempo depois casou-se com Maria, filha de Manuel. Uma vez mem- 
bro da família, seguiu-lhe o destino que o conduziu, com todos os outros, a Catulé.

OLÍMPIO B. F. - casou-se em 1913 aproximadamente com Benedita da C. T. Moravam então no município de Novo Cruzeiro e lá trabalhavam na qualidade de agregados. Em Novo Cruzeiro nasceram os primeiros filhos: José, em 1915 mais ou menos; Servino, Manuel e Ângelo, que morreram "miudinhos", e Mariana. A menina era ainda pequena quando deixaram Novo Cruzeiro e entraram no atual município de Malacacheta, cujas terras percorreram até chegar a Santa Cruz, onde o padrinho de Olímpio já se encontrava e onde havia "tirado uma posse". Em Santa Cruz nasceram os outros: Trajano, Pedro, Antônio, Maria, Amélia, Joaquim, João, Artuliana. Esta última nasceu por volta de 1935 e, logo depois do seu nascimento, o pai morreu. Naquele mesmo ano José casou-se com Eva, uma viúva proprietária de algumas terras em Taquaral; a família B. inteira mudou-se com José para Taquaral, mas a terra de Eva "era ruim... e os outros tiveram que sair porque não dava para todos". O primeiro a partir foi Trajano que, depois de se casar, emigrou para São Paulo com a mulher e um dos filhos. Encontrou trabalho nas plantações de algodão de Presidente Prudente de onde saiu somente depois de viúvo, para casar-se de novo ${ }^{22}$. Uma vez casado, voltou a Presidente Prudente onde mora até hoje.

Depois da partida de Trajano, a família B. deixou Taquaral por Jacutinga, onde "moravam como parceiros na propriedade de M. R.". Em Jacutinga, Pedro casou-se e emigrou para Presidente Prudente; Joaquim acompanhouo; porém, enquanto este último voltou, Pedro ficou. Antônio deixou a família em Jacutinga quando, tendo casado com a filha de um "arranchado", foi lavrar a terra do sogro e depois, "não se dando bem na casa do sogro", disse à mulher que ia trabalhar em Poté e, em vez disto, fugiu para Presidente Prudente. Amélia e Maria casaram-se quando a família ainda habitava em Jacutinga. $\mathrm{O}$ marido de Amélia é arranchado, o de Maria é agregado. Quando Joaquim voltara de São Paulo a família deixara Jacutinga para ir a Jacu, onde Benedita se amasiara. Este segundo companheiro, J. S., era arranchado. Com Benedita e José viviam Mariana, João, Artuliana e também Joaquim ao voltar. Moraram em Jacu até a morte de José, quando a filha legítima deste último os obrigou a partir; Joaquim queria voltar a São Paulo, mas conheceu Onofre e, sendo já "crente", foi por este convidado a permanecer e a unir-se ao grupo de "crentes" que se ia formando em Catulé. Em 1953 a família B. mudou-se, pois, para Catulé onde, nesse mesmo ano, Benedita morreu.
22. Trajano não quis casar-se em São Paulo "porque lá é o rapaz que tem que fazer as despesas do casamento. Aqui o rapaz só paga o casamento civil, pelo resto os pais da noiva pagam tudo; pagam o padre e dão os "trem da casa". 
Poderia parecer que o material apresentado tenha unicamente por fim reunir num mosaico um tanto confuso as informaçôes obtidas sobre os habitantes de Catulé, em particular no que diz respeito às relações entre os indivíduos e entre as famílias. Todavia, um exame mais cuidadoso induz a considerar as relações de parentesco, compadrio e amizade, que há anos ligavam os membros do grupo, não como liames de caráter puramente pessoal porém antes como a base sobre a qual se apoiava a organização da estrutura social e sem a qual não poderiam adaptar-se à natureza do ambiente. Nas páginas que se seguem tentaremos esclarecer tais relaçóes ilustrando o modo em que vieram a formar-se.

A maioria das famílias reunidas na clareira denominada Catulé encontrara-se, pois, no triângulo formado pela confluência do rio Urupuca com o Jacutinga quando, para usar as palavras de Manuel S., naquelas terras "ainda não tinha ninguém". A principal atração exercida por aquela área sobre as pessoas que ficaram, por um motivo ou outro, privadas de terra, consistia no fato de ser mais fácil, em zonas isoladas, a ocupação pura e simples.

Uma vez ocupada a terra, constrói-se a casa de moradia perto dos terrenos cultivados.

Para construir a casa é necessária a participação de vários homens adultos. Depois de limpo o espaço onde deverá surgir, buscam-se e abatem-se as árvores apropriadas para formar o arcabouço, cavam-se os alicerces, erguese a estrutura e preparam-se as grades de madeira para sustentar os muros de terra (pau-a-pique); o teto é constituído de folhas de palmeira que descem lateralmente para cobrir os muros. A construção da casa é trabalho masculino, mas as mulheres ajudam. Fazem o serviço mais "maneiro" de "amarrar", carregam água, amassam barro. A casa compõe-se de um único ambiente, em geral retangular, dividido longitudinalmente por um tabique que separa o quarto mais amplo, em que se desenrola a maior parte das atividades e que serve também de quarto de dormir, de outros dois cômodos, menores, um dos quais é usado como cozinha.

A mobília consiste em poucos assentos, bancos e caixotes vazios, e às vezes, uma ou duas camas feitas de grades de bambu apoiadas nos muros e sustentadas por dois pedaços de pau.

"A casa caipira não se limita contudo a este centro. Parte apreciável das atividades domésticas e do próprio conforto pessoal se processam no seu exterior, de modo que cada casa é na verdade núcleo de um pequeno sistema de moradia. O milho é armazenado em paiol externo, e só o arroz e o feijão são guardados na residência. A este mínimo se anexa quase sempre o forno de 
barro com a sua coberta de sapé; e ao conjunto é que se pode realmente chamar de habitação rústica”²3.

Vários produtos, como o feijão e o arroz, são postos a secar no terreiro antes de peneirar e guardar. Criam-se galinhas e porcos e, havendo recursos, algumas cabeças de gado que o mais das vezes são "dados a meia" a pessoas que possuem terras de pasto ou criam animais para depois dividir com o proprietário as crias que houver; não faltam os cães de guarda, e os que podem têm um cavalo também, uma mula ou burro como animal de carga ou para cavalgar.

Perto da casa está a horta onde se plantam couves, cebola e alho; em geral o cuidado da horta cabe às mulheres e aos velhos. Cultiva-se, além disso, a cana de açúcar para o consumo imediato: os que têm uma prensa ou engenho fazem garapa, que bebem pura ou usam com café em vez do açúcar. Os campos estão a certa distância da casa e neles cultivam-se o milho, o feijão, o arroz e o amendoim; parte dos produtos são consumidos, parte são vendidos no mercado.

Também para preparar a terra é necessária a participação de um certo número de homens adultos (que tenham atingido o desenvolvimento físico para trabalhar "de machado") na fase inicial de "derrubada e roçado da mata". Tendo necessidade de abrir uma clareira na mata para plantar os seus produtos, o lavrador abate a vegetação mais espessa que, num segundo tempo, queima. A fase de preparação inicia-se durante os meses secos (de maio a agosto) para evitar que a chuva apague o fogo, e conclui-se quando, durante a estação das chuvas, a cinza da queimada penetra na terra, fertilizando-a.

$\mathrm{O}$ espesso mato que recobre essas regiões e a técnica da queimada tornam extremamente precária a ocupação num estado de completo isolamento, "enquanto é praticamente impossível a um lavrador que só dispõe de mão-de-obra doméstica dar conta do ano agrícola sem cooperação vicinal" ${ }^{24}$. A manutenção da ocupação baseia-se numa forma de auxílio mútuo que determina a formação de "grupos rurais de vizinhança que na área paulista se chamaram bairro. Este é, por assim dizer, a estrutura fundamental da sociabilidade caipira, consistindo no agrupamento de algumas famílias, mais ou menos vinculadas pelo sentimento da localidade, a convivência, as práticas de auxílio mútuo, as atividades lúdicas e religiosas. As habitaçôes podem estar próximas umas das outras, sugerindo por vezes um esboço de povoado ralo; e podem estar de tal modo afastadas que o observador poderá não discernir, nas casas isoladas que topa a certos intervalos, a unidade em que não obstante se congregam" 25 .
23. Antonio Candido de Mello e Sousa, $o p$. cit., cap. II, p. 31.

24. Idem, cap. I, p. 44.

25.Idem, cap. I, p. 38. 
O bairro, pois, é um fenômeno sociológico cuja estrutura é determinada pela relação que vem a estabelecer-se entre a mata e a técnica de exploração de que dispóem os que a povoam. Explica-se, portanto, como o grupo de famílias que, a partir de 1920 mais ou menos, entrou na zona de "mata fechada" incluída na confluência do rio Urupuca com o Jacutinga, veio a formar um "bairro".

A divisão do trabalho entre os membros de um bairro baseia-se na diferença de sexo: à mulher cabe cuidar da casa e dos filhos, ao homem, o trabalho do campo. "Trabalho de menina" - informam as mulheres de Catulé "é varrer, escolher mantimentos, arrumar a cozinha. Trabalho de moça é mais lavar, cuidar da casa, cozinhar, também costurar e trabalhar na roça. Serviço de mulher é mais pesado: deve cozinhar para mais gente, fazer farinha, torrar café, socar milho, cuidar da casa e das crianças. Se não têm filhos pequenos trabalham muito na roça, se têm filhos pequenos trabalham mais em casa e só vão para a roça quando o serviço está mais apertado. Trabalho de mulher velha é fiar, remendar, olhar crianças, escolher mantimentos. Tanto as mulheres como as moças e as velhas mexem com vasilhas, algumas sabem fazer peneiras". As tarefas mais pesadas, como a "derrubada e o roçado da mata" cabem ao homem, o qual - se for casado ou morar ainda em família - deixa, à mulher, à mãe ou a uma irmã já adulta, as preocupações domésticas, para dedicar todo o seu tempo ao cuidado dos campos. Aos homens cabe, além disso, o transporte de "cargas pesadas" e manter contatos com os grupos vizinhos e o mercado; o que, freqüentemente, impóe verdadeiras viagens, o mais das vezes a pé. Alguns dos homens sabem fazer peneiras, balaios de taquara e gamelas (de gameleira, de cedro e de marunga) para o uso familiar.

Esses breves informes sobre a divisão do trabalho são suficientes para fazer compreender as dificuldades que um homem, para não falar na mulher, encontraria neste ambiente se quisesse viver sozinho. "Casar é indispensável ao indivíduo, não se reconhecendo viabilidade ao celibato mascu-

26. Antonio Candido, "A vida familial do caipira”. Sociologia, São Paulo, vol. XVI, n. 4, p. 342.

27.Idem, art. cit. p. 342. lino" ${ }^{26}$. O matrimônio, além disso, torna-se necessário não só pelas condições de trabalho, mas também pelo fato de representar a solução do problema sexual, pois "sem companheira o lavrador pobre não tem satisfação de sexo, auxílio na lavoura, alimentação regular. Em princípio, os dois últimos problemas não se colocam enquanto os pais vivem, pois a solidariedade intrafamiliar remedeia a ambas as necessidades e a mãe faz as vezes da mulher economicamente requerida. Mas considerando que eles acabam antes dos filhos, é necessário a estes tomar estado e assumir iniciativa econômica” ${ }^{27}$. 
Do mesmo modo, para a mulher, o matrimônio "é condição de estabilidade e segurança, visto que, falecidos os pais, a solteira fica praticamente sem posição definida. Os padrões correntes acentuam a vida de pena e sacrifício da esposa - o que todavia não parece constituir empecilho ao desejo de arranjar marido e casa" 28 .

A importância econômica do casamento, seja para o homem seja para a mulher, explica, a nosso ver, a brevidade dos períodos de viuvez.

Tomemos como exemplo o caso de Geraldo R. dos S. e o de Cristina G. S.

Por morte da primeira mulher, Geraldo tinha 27 anos; o maior dos seus três filhos tinha 9 anos. "Quando morre a mãe” explica Geraldo, "é difícil para o pai cuidar dos filhos; se não tem uma moça já grande que zele pelos pequenos, ou casa outra vez ou distribui os filhos". A mulher morrera em Catulé e Leonora, filha de Manuel S., "zelou da casa e das crianças, cozinhava e lavava roupa. Ficou ela porque as outras mulheres tinham casa e filhos enquanto Leonora era ainda solteira e podia. Não casaram porque são primos e ela é sua comadre. Casamento de compadre com comadre não dá certo, se casar sai sempre muita briga". Visto que no grupo de Catulé não havia mulheres disponíveis, Geraldo voltou a Urupuca, bairro que deixara havia pouco, e onde "arranjou outra mulher".

Cristina ficou viúva pela primeira vez aos 19 anos. Quando morreu o marido, a terra passou aos irmãos dele. Alguns meses depois Cristina uniuse a João S., irmão de Manuel; morto João, depois de quatro anos de convivência, a terra passou aos filhos da primeira mulher, que eram "legítimos". Neste caso, quer-nos parecer, a terra passou aos filhos da primeira mulher, não somente, e talvez nem tanto por serem legítimos, mas sobretudo por serem adultos. De fato, mesmo que a terra tivesse ficado para a viúva, não tendo ela filhos adultos, não teria podido conservá-la, porque é o homem e não a mulher que participa da troca de dias-trabalho que permite ao "posseiro" "capitalizar" a força-trabalho necessária à manutenção da posse. Daí resulta que, se a família não tem quem a represente no sistema de "cooperação vicinal" - ao qual só tem direito quem dele participa a sua vida econômica fica paralisada. À viúva sem filhos adultos oferece-se a alternativa: casar de novo ou dirigir-se a um "compadre" ou a um "padrinho". Cristina valeu-se da primeira solução e casou-se quase imediatamente com João T. dos S. Viveu com ele dezesseis anos. Por morte do marido, tinha 41 anos, uma idade que lhe teria permitido novo casamento, se o desejasse; mas, naquela época tinha filhos já adultos que podiam "tomar conta dela e da roça”.
28. Idem, art. cit. p. 350 . 
Francisca e Maria, ao contrário, valeram-se da segunda solução e dirigiram-se a Manuel S., "compadre" da primeira porque o marido dela, Antônio, batizara-lhe a filha maior; e "padrinho" da segunda, como testemunha de casamento do marido dela, Abrão. Ambas as viúvas desfizeram-se da terra quando se agregaram a Manuel S. e moraram com ele até que os seus respectivos filhos maiores, João e Adão, se tornaram adultos.

A principal função do sistema de compadrio parece ser a de prover cada membro de uma comunidade - no nosso caso um bairro - de pessoas ("compadres" e "comadres") a quem possa recorrer - e das quais por sua vez estará à disposição - em caso de necessidade, como também prover certo número de pais espirituais ("padrinhos" e "madrinhas"), prontos a ajudar os membros mais jovens quando for preciso. $\mathrm{O}$ indivíduo adquire esse pais espirituais por ocasião do batismo, da crisma e do casamento religioso. No momento do batismo, a criança adquire um padrinho e duas madrinhas, freqüentemente escolhidos entre irmãos e irmãs dos pais; das duas madrinhas, uma é a que estende o recém-nascido ao sacerdote na fonte batismal; a outra chama-se "madrinha de carrego" ou "de represento" e é sua tarefa carregar a criança da casa à igreja e vice-versa. A madrinha de carrego, sobretudo se a igreja é longe da moradia, é mais jovem do que a outra, e por conseguinte os pais espirituais do recém-nascido escalam-se no tempo. Se o padrinho e a madrinha são casados, os seus cônjuges tornam-se, respectivamente, madrinha e padrinho da criança e comadres e compadres dos pais. Por ocasião da crisma, a criança adquire, conforme o sexo, mais um padrinho ou mais uma madrinha (além dos respectivos cônjuges) e os pais outros compadres. Finalmente, ao casar, os esposos adquirem tantos padrinhos e tantas madrinhas quantas forem as testemunhas (com os respectivos cônjuges). O compadrio, pois, fornece ao novo membro da comunidade uma série de pais e mães que o assistem desde os primeiros anos de vida até o matrimônio, pois esta última cerimônia, sendo índice de independência econômica finalmente atingida, representa, a nosso ver, o primeiro passo para uma mudança de status das duas pessoas ligadas pela relação "padrinho-afilhado". Quando o afilhado se torna pai e convida, segundo o costume, o padrinho e a madrinha de casamento a batizar o primogênito e também um dos filhos sucessivos, torna-se desse modo compadre do seu padrinho de casamento. Com o nascimento de um filho, portanto, o jovem pai e a pessoa que o seguiu durante a primeira juventude podem, se quiserem, abandonar as respectivas posiçóes de afilhado e padrinho para tomar a de compadre, encontrando-se assim no grupo dos adultos. 
Com o ingresso do afilhado neste grupo, isto é, no grupo formado pelos homens economicamente autônomos, inicia-se a exclusão gradual dos expadrinhos (cujos afilhados se vão tornando adultos), os quais, envelhecendo, entram a fazer parte do grupo dos anciãos, ou seja de um grupo formado por pessoas que já não gozam de autonomia econômica, embora, às vezes, conservem o seu prestígio social. Poder-se-ia porém objetar que, se a função de compadrio, como dissemos, está em ampliar o círculo de relações do indivíduo, ligando-o a pessoas economicamente autônomas, parece que o sistema se contradiz no momento em que o jovem pai pede a uma pessoa, que está prestes a perder a sua autonomia econômica, que se torne seu compadre e padrinho do seu filho.

Citamos, para maior esclarecimento, dois exemplos: Manuel S., como vimos, nasceu em 1890. Sua mulher, Ana, batizou Geraldo R. dos S.; quando este se casou com Rita, irmã de Jacinta, Manuel foi testemunha; em 1947 o casal teve um filho, José Luiz, e Manuel foi convidado a batizá-lo. Manuel tinha então 57 anos, estava, pois, em idade um tanto avançada para oferecer garantias de proteção a José Luiz. Manuel foi também testemunha de João de Francisca quando este se casou, aos 18 anos, em 1945. Em 1950, Manuel contava 60 anos, João teve um filho, André, que foi batizado por Manuel. Também neste caso pode-se indagar que garantias de proteção poderia Manuel oferecer a André. E, se não analisarmos o problema de outro ponto de vista, o sistema de compadrio parece perder a sua função. Suponhamos, pois, que a mudança de status das pessoas, ligadas pela relação padrinho-afilhado, indique a possibilidade de inversão da própria relação, ou, para formular o problema com uma pergunta: é possível que o sistema de compadrio funcione em duas direções, isto é, adulto para recém-nascido e adulto para velho? Esta hipótese que não é de modo algum contrária à função intrínseca do compadrio, baseia-se no fato seguinte: assim como a criança precisa de proteção até o momento da maturidade, também o ancião necessita de ajuda à medida que vai perdendo a autonomia econômica, e só pode garantir essa ajuda tornando-se compadre dos seus afilhados.

A aceitarmos a hipótese da inversão no funcionamento do sistema de compadrio, é evidente a vantagem que Manuel - e não José Luiz ou André - tira, adquirindo, em idade já avançada, dois compadres jovens como Geraldo e João (pessoas, entre outras coisas, a ele ligadas por dívidas especiais de gratidão) os quais podem agora, e estão em condições de fazê-lo pelo fato de se terem tornado compadres, pagar as obrigaçóes acumuladas no período em que eram afilhados. 
Dada a importância do compadrio, das três cerimônias que o determinam, duas, isto é, o batismo e o casamento, são particularmente respeitadas pelo tipo de comunidade que estamos estudando, embora tais grupos sejam, em geral, muito indiferentes, devido ao isolamento em que vivem, a outras instituições quer civis quer religiosas de caráter nacional. Todos em Catulé são batizados e todos, com exceção de Geraldo A. P. e Leonora, que se casaram depois de sua conversão ao Adventismo, são casados no religioso, pelo menos uma vez. De fato, a nosso ver, para os fins do compadrio não é preciso que os matrimônios sucessivos ao primeiro sejam regularmente celebrados na igreja, uma vez que a pessoa que perde o cônjuge e o substitui - quer se trate do viúvo que torna a casar ou da mulher que "largada pelo primeiro marido, arranja outro" - "herda" por assim dizer, os padrinhos, as madrinhas, os compadres e as comadres que se criaram com a primeira cerimônia.

Geralda, segunda mulher de Geraldo R. dos S., por exemplo, chama de padrinho a Manuel S., cuja terceira mulher, Ana, batizou Geraldo; alémdisso, chama de madrinha a Francisca porque o marido desta, Antônio, fora padrinho de batismo de Geraldo; considera-se além disso comadre de Jacinta, Leonora e Germana (e dos maridos das duas primeiras, visto que Germana não é casada) porque batizaram os filhos de Rita, primeira mulher do seu marido; ademais, é duas vezes comadre de Jacinta porque Rita, irmã desta última e, como vimos, primeira mulher de Geraldo, foi madrinha "de carrego" do filho de Jacinta, André.

Os exemplos poder-se-iam multiplicar ao infinito, mas este ilustra com clareza que as relações criadas por meio do compadrio não estão ligadas à pessoa que as determina, mas são posições estáveis cujas responsabilidades devem ser aceitas por quem as ocupa.

A importância do compadrio, além disso, afigura-se ainda mais evidente se observarmos como os dois fatores, que determinam a formação do bairro, isto é a natureza do solo e a preparação técnica de quem o afronta, agem também em sentido inverso, limitando o período de tempo durante o qual o bairro permanece coeso.

Nenhuma das famílias de Catulé, por exemplo, ocupara a mesma terra por três gerações consecutivas (e ninguém conhecia outras pessoas que o tivessem feito) ou porque o bairro é uma unidade "itinerante" ou pela ação de outro fator a que podemos chamar "demográfico".

A razão por que o bairro é unidade "itinerante" afigura-se evidente se examinarmos o ciclo da agricultura extensiva, baseada na queimada, que 
consta de três fases: "aproveitamento do terreno da mata, degradação desta a capoeira, destruição de nova mata" 29 .

“Terra de mata”, segundo os nossos informantes, “é boa mas não logo na primeira queimada. Terra de primeira queimada é terra brava porque tem um bichinho que come as raízes das plantas; podendo, a gente deixa descansar um ano, para ficar bem boa”. Os produtos principais, como dissemos, são o feijão, o milho e o arroz; desses três produtos, "o feijão cansa mais a terra, porque é preciso limpar todo o terreno quando colhem; depois de dois anos já é preciso deixar crescer a capoeira. $\mathrm{O}$ milho não cansa tanto porque o resto lhe serve de adubo". Calcula-se que o tempo médio, durante o qual a terra tomada à floresta por meio da queimada pode ser cultivada com proveito, cobre um período que varia de três a quatro anos; depois, a terra "fica muito batida" e precisa repousar.

Para poder praticar a agricultura, pois, o bairro precisa de um território (mais ou menos vasto conforme o número de famílias que o compõem) no qual o lavrador possa deslocar-se para cultivar, com os produtos mais adequados, determinadas porçôes de terreno e deixar descansar outras.

Embora não haja dados a respeito, é evidente que o máximo de população do bairro será determinado pelo território disponível e pelo sistema de "cooperação vicinal"; esse sistema, tal como o descrevemos acima, impõe, com efeito, limites bem precisos de espaço e de tempo. Se o território do bairro é demasiado vasto, as horas de trabalho investidas na roça de um dos membros não compensam o tempo perdido para chegar ao lugar; e se o número de famílias aumentar excessivamente, faltará o tempo de praticar com todas a troca de trabalho; em ambos os casos, portanto, o sistema de "cooperação vicinal" deixaria de funcionar. Daí resulta um movimento cíclico de expulsão do excesso demográfico, cada vez em que o máximo é atingido, e um reforço da tendência "itinerante".

Por um lado, de fato, "a extensão da área cultivada por cada um dos parceiros, bem como o êxito de trabalho dependem do número de braços com que pode contar cada um"30; os habitantes de Catulé aceitam essa opinião e confirmam que "os filhos dão despesas quando pequenos, mas ajudam bastante depois que crescem", "família grande djutora (sic) mais, rompe mais para a frente". Na realidade, embora um menino comece a trabalhar na roça aos 7 anos ("faz uma capinada, racha lenha etc.") somente por volta dos 12 anos, isto é, quando "começa a pegar na foice" adquire verdadeira utilidade econômica; a partir desse momento, a família começa a gozar as progressivas vantagens de ter no seu seio um trabalhador que produz mais do que conso-
29. Antonio Candido de Mello e Sousa, $o p$. cit., cap. I, p. 11.

30. Idem, cap. II, p. 21.

junho $2008 \quad 339$ 
me. $\mathrm{E}$ isso porque, quanto maior for o número de homens adultos na família, tanto maior é o capital de força-trabalho de que a família dispõe e tanto maiores as vantagens que ela tira do investimento desse capital no sistema de "cooperação vicinal", cujo rendimento, como vimos, é proporcional à participação. Ademais, como a importância econômica do homem não se limita à família mas estende-se ao bairro todo (porque aumenta a força-trabalho à disposição das famílias que o compõem) parece haver uma tendência a incorporar, via matrimônio, o lavrador isolado que entra no território de um bairro. A esse propósito podemos citar o caso de Manuel S., "incorporado", por assim dizer, pela família da segunda mulher, "gente arranchada"; e o de Abrão, "incorporado" pelas famílias Soares, R. dos S., mediante o matrimônio com Maria, irmã de Francisca R. dos S.

Por outro lado, porém, tanto a incorporação de um homem à família nuclear, como a manutenção na família dos filhos adultos que se casam, tornam-se antieconômicos no momento em que os novos casais começam a ter filhos, isto é, agregam ao bairro novos membros que, durante os primeiros doze anos de vida, representam um passivo econômico. Neste caso, a vantagem trazida pelo homem adulto com a conquista, direta ou indireta, de um ulterior terreno para cultivar já não está em proporção com o rendimento do próprio terreno que, agora, deve manter tanto a família paterna, da qual o casal ainda faz parte, como a família em formação. A família paterna "gera" portanto outra família nuclear que pode permanecer no território do bairro, se este a contiver, mas deve ir-se embora se a economia do bairro vier a sofrer com isso, uma vez que o círculo de "cooperação vicinal" não pode pôr em risco a própria eficiência, alargando-se por motivos puramente sentimentais. O excesso demográfico, formado por pessoas que vivem na mesma terra e são dotadas da mesma técnica, repetirá o fenômeno "bairro" em novas zonas de "mata fechada". Esse novo bairro, a que chamaremos bairro B, não é, na maioria dos casos, uma filiação direta do bairro $\mathrm{A}$, mas recolhe as famílias "eliminadas" dos vários bairros A (A-1, A-2 etc.) para manter o equilíbrio sociológico; em outras palavras, os vários bairros $\mathrm{A}$, além de um território suficiente para praticar a agricultura seminômade e manter-se portanto coesos, têm também necessidade de terras em que possam despejar os excessos cíclicos de população. Por conseguinte, as famílias que vierem a fazer parte do bairro B serão o mais das vezes estranhas entre si (ver por exemplo as famílias que em 1920 participaram da formação do bairro de Urupuca) e substituirão a falta de tradiçôes de ajuda mútua, baseadas nos vínculos de parentesco, adotando um sistema tradicionalmente fundado sobre a cooperação, isto 
é, o compadrio, o qual, juntamente com o matrimônio, representa o elo que cimenta o novo bairro B.

Em resumo, vimos que dois fatores determinam a formação de um bairro: um é representado pelas características do solo tropical, o outro pela preparação técnica do homem que o afronta. Esses dois fatores determinam não só a formação do bairro mas firmam-lhe a estrutura impondo aos seus membros "trabalhos de ajuda mútua": "É membro do bairro quem convoca e é convocado para tais atividades. A obrigação bilateral é aí elemento integrante da sociabilidade do grupo, que desta forma adquire consciência de unidade e funcionamento" ${ }^{31}$. Os vínculos de trabalho transformam-se freqüentemente em vínculos de parentesco, pois, como observamos, as condições de vida na "mata" impõem, de um lado, o casamento como solução de problemas econômicos e sexuais, de outro, limitam, devido ao isolamento em que vive o bairro, a escolha do cônjuge. Além disso, as eventuais emergências provocadas pelas precárias condiçôes de vida do bairro são afrontadas mediante o compadrio, que funciona como um sistema de segurança social para ajudar os membros mais jovens da comunidade, provavelmente para garantir a velhice, e, por fim, para dar ajuda aos adultos que se encontrem em condiçôes difíceis. Ademais, é inerente à economia do bairro e à agricultura "itinerante" por ele praticada a eliminação do excesso demográfico; enquanto conclui o precedente, esse movimento marca o início de um novo ciclo e a repetição do fenômeno bairro em outra zona de mata fechada; os membros do novo grupo adotarão, por sua vez, o matrimônio e o compadrio para consolidar a estrutura do bairro e garantir-lhe a coesão.

Uma vez descritos, embora brevemente, a formação e o funcionamento de um bairro, passaremos agora a analisar as causas externas que, na zona do Urupuca, provocaram a sua desorganização.

"Quando eu era menino" disse-nos um dos habitantes de Catulé, "só havia duas fazendas, o resto do terreno era mata e cada um tinha uma posse. Agora é tudo fazenda grande". A formação da propriedade privada, no território ocupado pelo bairro de Urupuca, foi, a nosso ver, a causa principal da sua desorganização. Os primeiros indícios de que a propriedade privada atingira o grupo do Urupuca remontam a 1940 mais ou menos, isto é, à época em que Abrão é obrigado a "vender" a terra cedendo à prepotência de vizinhos mais fortes. O episódio é significativo porque mostra como no Urupuca se começou a "vender e comprar" terra, fato tão estranho aos hábitos e à economia do bairro que revela a presença de recém-vindos.
31. Idem, cap. I, p. 43. 
32."Rodovia RioBahia”. A Rodovia, ano X, n. 104 , p. 15 , set. 1948.

33.Eng. Ant. Furtado da Silva, "A Rodovia Rio-Bahia". A Rodovia, ano IV, n. 19, p. 67, ago. 1941.

34.A Rodovia RioBahia”. A Rodovia, ano VIII, n. 69, p. 34, out. 1945.

35.C. S. p. 39.

36. A Rodovia, ano VIII, n 68, p. 10, set. 1945.
Essa zona despertou a atenção da propriedade privada devido ao projeto de construção de uma estrada de rodagem, cujo trecho mais longo atravessaria o Estado de Minas Gerais, tocando zonas até então isoladas, e que uniria a capital federal à Bahia.

A rodovia Rio-Bahia (Br-4) é em si uma estrada de penetração; no conjunto nacional, o elo entre o norte e o sul do Brasil. Seu traçado, cerca de $1.700 \mathrm{~km}$, desenvolve-se à distância média de $250 \mathrm{~km}$ do litoral. Atravessou regiōes inteiramente virgens, no sertão mineiro e no chapadão baiano. Três Estados, Rio de Janeiro, Minas Gerais e Bahia, foram cortados, tornando possível uma real ligação $[\ldots]^{32}$.

\section{As obras começaram em 1937 e}

[...] dos sete traçados ou variantes estudados [...] foi afinal escolhido o traçado por Areal, Porto Novo, Leopoldina, Muriaé, Caratinga, Figueira, Teófilo Ottoni, Fortaleza, Conquista, Jequié e Feira de Santana por apresentar vantagens incontestáveis: é o mais curto dos traçados possíveis, atravessa a zona da Mata, uma das regiōes mais ricas, povoada e fértil do Estado de Minas Gerais; atravessa o vale do rio Doce que constitui a nossa maior reserva florestal nas proximidades da Capital, de enormes possibilidades agrícolas, e encerra riquezas minerais extraordinárias em mica e pedras coradas. A vila de Governador Valadares, em 1940, exportou cerca de 20.000 contos de mica, e o município de Teófilo Ottoni exportou mais de 15.000 contos de pedras coradas. O vale do Mucuri é outro manancial inesgotável em riquezas minerais e agrícolas, até hoje quase desconhecido e inexplorado, por falta de vias de comunicação. O vale do Jequitinhonha, outro empório de pedras coradas e diamantes, encerra, além disso, uma vasta zona onde a pecuária, já bastante desenvolvida, encontrará possibilidades extraordinárias, nas extensas campinas banhadas pelas águas salitradas de alguns de seus afluentes. Salinas, Fortaleza, Jequitinhonha e Joaima são cidades florescentes devido às grandes boiadas que apascentam em suas campinas e que anualmente são exportadas para os centros consumidores. $\mathrm{O}$ erguimento de uma grande indústria de laticínios nesta região aguarda apenas o estabelecimento de uma via de comunicação $[\ldots]^{33}$.

Embora as obras começassem em 1937, somente em 1944 terminou a construção da ponte sobre o rio Doce ${ }^{34}$ e a ligação entre Governador Valadares e Teófilo Ottoni ${ }^{35}$. No que concerne a ligação de Teófilo Ottoni com o norte, a primeira notícia a propósito aparece em 1945, ano em que a revista $A$ Rodovia ${ }^{36}$ publicou a seguinte comunicação: 
O departamento Nacional de Estradas de Rodagem construiu há pouco o trecho Teófilo Ottoni-Rio Jequitinhonha da rodovia Rio-Bahia que permite a comunicação por terra ao norte do país [...]. Já se vai, para usar uma linguagem comum, do Rio a Salvador de automóvel, e em quatro ou cinco dias. O conteúdo social e econômico dessa realização é de uma importância sem par, porquanto não significa só os interesses que se relacionam com a nossa segurança, mas significam também a valorização de populações secularmente segregadas. Sob este aspecto principalmente é que a ligação rodoviária Rio-Bahia deve ser considerada.

De fato, uma das funções da Rio-Bahia seria a de povoar e enriquecer as regiōes que atravessava.

Se, como asseguram os peritos ${ }^{37}$, a construção de uma estrada de rodagem valoriza, nuns cinqüenta quilômetros de profundidade, as terras que a ladeiam, e essa opinião parece confirmada pelos dados referentes à presença, justamente por volta de 1940, de novos vindos à zona do Urupuca, a abertura da Rio-Bahia exerceu a sua influência não só no município de Poté, cuja sede dista cerca de $45 \mathrm{~km}$ de Teófilo Ottoni, mas também no de Malacacheta, mediante a abertura da estrada municipal Teófilo Ottoni, Poté, Malacacheta, que contribuiu para a penetração de tal influência ainda mais para dentro.

A ligação, pois, de uma zona tão isolada aos centros de mercado, determinou a valorização das terras do município de Malacacheta ou, pelo menos, levou muita gente a crer que essas terras se valorizariam. Daí resultou um movimento tendente à ocupação das terras devolutas do município, movimento com fins mais especulativos que de colonização agrícola. De fato, a formação da propriedade privada, nessa zona, não indica de modo algum uma tendência a investir capitais em terrenos para lavoura, mas revela, ao contrário, uma tendência a legalizar a propriedade dos terrenos com o fim de garantir o direito de venda. Esse jogo especulativo - em parte devido à falta de meios dos recém-chegados, os quais, se de um lado não queriam ser posseiros, de outro, não tinham capital suficiente para "formar uma fazenda" favorece a criação da propriedade privada de caráter latifundiário, cujo aumento pode ser estatisticamente indicado pelos dados na Tabela a seguir ${ }^{38}$.

A terra passa (numa seqüência que serve mais para esclarecer os tempos de um processo histórico do que a maneira em que se realizou) das mãos dos posseiros às dos que vinham ocupá-la, e destes a pessoas com capitais suficientes para comprá-la e garantir a propriedade cercando-a e fazendo-a medir por agrônomos enviados pelos departamentos competentes para
37. Desejamos agradecer ao dr. E. Régis Bittencourt por nos ter gentilmente fornecido a biografia de $A$ Rodovia e, em conversa particular, as suas opiniōes sobre o raio de influência exercida pela construção de uma nova estrada.

38. Os dados do censo relativos ao município de Malacacheta para 1950 foram-nos gentilmente fornecidos pelo Serviço Nacional de Recenseamento do Rio de Janeiro. 
39. A história da formação da propriedade privada em zonas de terras devolutas é farta em incidentes violentos e, embora os posseiros fossem indenizados, as transações ocorriam numa atmosfera de abuso cuja lembrança se conserva em histórias mais ou menos exatas (por exemplo a de Manuel S. indenizado por três alqueires quando perdia trinta) e mais ou menos autênticas, que porém revelam a moral comercial da época. Conta-se por exemplo que uma mulher vendeu milho a um fazendeiro, um desses que "faziam vida lançando o gado na roça dos outros". O fazendeiro disse à mulher que era preciso legalizar a venda do milho e levou-a ao "cartório" onde se legalizavam as compras e vendas de terrenos. Lá ele lhe perguntou na presença de autoridades competentes: "A senhora não vendeu?" A mulher respondeu que sim e perdeu a terra. legalizá-las; ou então a pessoas que, embora não tendo os meios para comprar a terra, tinham bastante dinheiro para tomar essas duas medidas de precaução, necessárias para defender a propriedade ${ }^{39}$.

\begin{tabular}{l|c|c}
\hline Área em Hectares & \multicolumn{2}{|c}{ Porcentagem Das Propriedades } \\
\hline \multirow{3}{*}{$2-5$} & 1940 & 1950 \\
\cline { 2 - 3 } $5-10$ & 0,6 & 2,4 \\
$10-20$ & 4,8 & 6,4 \\
$20-50$ & 16,6 & 15,0 \\
$50-100$ & 48,2 & 44,0 \\
$100-200$ & 17,0 & 17,8 \\
$200-500$ & 8,8 & 7,6 \\
$500-1000$ & 3,2 & 4,7 \\
Além de 1000 & 0,5 & 1,0 \\
& 0,3 & 1,1 \\
\hline
\end{tabular}

A fase mais violenta desse processo concluiu-se, pelo menos para o nosso grupo, por volta de 1948, época em que Manuel S., depois de ter em vão e por duas vezes tentado "tirar uma posse" (em vão porque não conseguiu defendê-la do ataque dos vizinhos) chegou à conclusão de que "lugar para mim é bestagem" e começou a "morar de favor" na qualidade de agregado nas terras que J. A. de Q. possuía à beira do rio Urupuca.

A expressão "morar de favor" descreve com agudeza a situação em que vieram a encontrar-se os ex-posseiros no momento em que a terra passou a ter um dono. $\mathrm{O}$ proprietário territorial, de fato, pode negar aos lavradores licença para instalar-se em suas terras, e, quando a concede, é seu direito determinar as condições, ou, em outras palavras, estabelecer em que medida o agricultor deve pagar-lhe pelo uso da terra dando-lhe uma certa quantidade do seu produto. Esse contrato, conhecido pelo nome de "parceria", desorganizou a vida econômica do ex-posseiro porquanto, não tendo a propriedade privada trazido nenhum melhoramento ao sistema de trabalho, e não tendo, pois, aumentado a produção, o imposto que o ex-posseiro tinha de pagar ao fazendeiro privava-o da pequena margem que, em outros tempos, lhe permitia estabelecer relações com o mercado. As necessidades do parceiro permanecem ("a gente precisa de dinheiro para comprar no comércio café, banha, sal, os trens pra trabalhar, fazenda etc.") e talvez aumentem, fazendo aumentar a necessidade de recorrer ao mercado, enquanto diminuem os meios de satisfazer a tais necessidades, seja por causa do 
imposto, seja pelo fato de não ter a produção do parceiro o mesmo valor comercial que a do fazendeiro, devido às condições de oferta e procura.

Ilustramos o caso baseando-nos no material colhido em Catulé. O primeiro contrato estipulado pelo grupo tinha a duração de dois anos (1952$1954)^{40}$ e devia respeitar as seguintes condições: durante o primeiro ano os lavradores derrubariam a mata, sem pagar nada ao patrão; no segundo ano dar-lhe-iam $20 \%$ da produção do arroz e nada sobre outros produtos cultivados. É preciso, porém, levar em conta que o arroz é o produto comercialmente mais interessante e que, além disso, o fazendeiro pode, se quiser, comprar parte dos $80 \%$ remanescentes pagando-o ao preço que julgar conveniente, porque "é arroz de suas terras". O que resta ao lavrador será em parte conservado para o consumo e parte vendido. Mas o arroz do parceiro, como de resto qualquer produto seu, vale menos que o arroz do fazendeiro, porque o seu mercado de venda é limitadíssimo. Os habitantes de Catulé, por exemplo, podiam contar somente com três compradores fixos: o fazendeiro, o administrador da fazenda e o irmão deste último. O limitadíssimo número de compradores influi, evidentemente, sobre o preço de venda. Vender ao mercado de Malacacheta, por outro lado, era difícil pela falta de animais de carga: "Em Malacacheta a gente vende na feira as coisas mais leves de carregar, frangos, ovos, farinhas".

Se as condiçōes de venda são desfavoráveis, também o são as de compra porque

[...] a alta dos preços nos artigos comerciais se liga funcionalmente às variações dos preços obtidos pelos seus produtos agrícolas, para determinar o equilíbrio da economia doméstica. Ora, o mais freqüente em nossos dias, é que a subida permanente dos primeiros é contrastada por altos e baixos nos segundos; altos e baixos tanto mais freqüentes quanto a produção agrícola varia em volume de ano para ano, não apenas em virtude dos fatores econômico-sociais, como, supondo-os estáveis, das modificações climáticas. Verifica-se, pois, para o caipira, uma primeira discrepância entre a regularidade das condições de compra e a irregularidade das condições de venda. Segunda discrepância se registra entre as condições gerais do mercado de produtos agrícolas, e as condições especiais de vila, cidade ou região, sobretudo no que tange aos gêneros produzidos pelo pequeno lavrador. A formação de preços de gêneros, produzidos em pequena escala pelos parceiros e sitiantes, depende não apenas das condições gerais do mercado num dado momento, mas da oferta freqüentemente arbitrária dos compradores locais, motivada pela saturação progressiva do mercado regional, as possibilidades de exportação, o jogo de intermediários
40. A brevidade dos contratos é desvantajosíssima para o agregado, que muitas vezes não consegue gozar os frutos do seu trabalho de derrubada e de cultivo das plantações. Quando os agregados precisam deslocar-se, efetivamente são obrigados a deixar tudo o que plantaram, por exemplo mandiocais que ainda estão em produção. Depois de se terem tornado agregados, dizem-nos as pessoas de Catulé, trabalharam menos: "antes fazíamos roças maiores mas depois mudamos tantas vezes $\mathrm{e}$ perdemos todo o serviço e esmorecemos". Uma das cláusulas do contrato estabelece que é proibido plantar árvores frutíferas, bananeiras e laranjeiras, e construir casas melhores. Isso para evitar que com a contribuição de melhoramentos o agregado possa alegar direitos sobre a terra ou pedir indenizações. Se plantarem árvores frutíferas, especifica o contrato, não podem pretender indenização alguma por esse fato. 
41. Antonio Candido de Mello e Sousa, $o p$. cit., cap. III, p. 4. e especuladores, sobretudo aqueles que visam ao lucro obtido pelo afastamento máximo entre preço de compra e preço de venda em lugares diferentes. Junte-se a isto o fato de o pequeno agricultor não ter informação sobre o preço real do seu produto nas grandes cidades consumidoras, e precisar vendê-lo rapidamente para solver o compromisso com o comerciante, que é, nas vilas, ao mesmo tempo o seu vendedor e comprador” ${ }^{\prime \prime}$.

No caso de se encontrar o lavrador em situação de emergência, e, necessitado de dinheiro, já não tendo o que vender, "precisa pedir dinheiro emprestado. Isso é muito ruim porque precisa vender na folha e quando colhe tem que entregar tudo". Comprando "na folha" o comprador corre um risco - do qual se garante oferecendo preços baixíssimos. Além disso, se a colheita não for suficiente para saldar a dívida contraída, o lavrador não pode, mesmo tendo a soma necessária, dar a diferença em dinheiro, e é obrigado a hipotecar uma parte da colheita do ano seguinte para pagar em espécie a dívida do ano em curso. No caso, então, de se esgotar a reserva de víveres antes da colheita, o lavrador, se não tiver dinheiro, compra "a troca de serviços" do fazendeiro ou do administrador da fazenda: um homem adulto recebe, em troca de um dia de trabalho, "uma medida" de feijão ou de arroz, ou de milho; as mulheres e os meninos de uns 12 anos ("bons para a foice" mas não ainda "para o machado") devem trabalhar dois dias para ganhar "uma medida".

Para reparar à falta de dinheiro, o parceiro tenta encontrar um meio de ganhar um salário recorrendo ao mercado para a mão-de-obra agrícola. No nosso caso tal mercado era bastante limitado porque, como se vê pelos dados na Tabela que se segue, tirados do Censo Econômico de 1940, a atividade econômica principal do município de Malacacheta era a criação de gado.

Foi somente no fim da década 1940-1950 que alguns proprietários começaram a "formar café" e a ter, portanto, necessidade de mão-de-obra agrícola. Os habitantes de Catulé, por exemplo, uma vez vencido o contrato estipulado em 1952, foram convidados a ficar para "formar café"; receberiam uma remuneração de cem cruzeiros por mil pés de café formados, mais um alqueire de terra para as suas plantações, enquanto, sobre a produção do arroz, continuariam a dar $20 \%$ ao fazendeiro. O contrato foi "fechado" e os lavradores esperaram as mudas de café; mas, em vez de mudas, receberam café em caroços. Isso constituiu para eles uma desvantagem, não só porque "formar café de caroços" é mais difícil, mas também porque o 
pagamento ao lavrador se efetua somente quando o café está "formado". Como dizem os habitantes de Catulé, "café de caroço brota no mesmo ano, o primeiro broto geralmente morre. Se a segunda brota se conserva até o segundo ano, está formado"; é somente no fim do segundo ano que o lavrador recebe a sua remuneração. Além disso, cultivando as mudas, que crescem mais rapidamente, entre as filas de café podem-se plantar logo outros produtos, ao passo que, cultivando caroços é preciso esperar a segunda brota. Portanto, enquanto ao fazendeiro convém mais plantar café de caroço (porque se crescer resistirá melhor às variações atmosféricas) para os agregados seria mais interessante plantar café de muda.

\begin{tabular}{|c|c|c|}
\hline MODALIDADE DA EXPLORAÇĀO & ESTABELECIMENTOS RECENSEADOS & ÁreA(HÁ) \\
\hline Agricultura & 520 & 18.962 \\
\hline Em grande escala & - & - \\
\hline Em pequena escala & 520 & 18.962 \\
\hline AgropeCUÁRIA & 1.322 & 82.785 \\
\hline Em grande escala & - & - \\
\hline Em pequena escala & 1.322 & 82.785 \\
\hline Pecuária & 49 & 15.427 \\
\hline Em grande escala & 20 & 10.718 \\
\hline Em pequena escala & 29 & 4.709 \\
\hline OUTRA MODALIDADE DE EXPLORAÇĀO & 32 & 1.599 \\
\hline
\end{tabular}

Fonte: IBGE - Recenseamento Geral do Brasil (1ำ de set. de 1940) - Série Regional - Parte XIII - Minas Gerais - Tomo 3 - Censos Econômicos, p. 336.

Outra possibilidade de trabalho remunerado foi oferecida aos lavradores de Catulé pelo administrador da fazenda o qual precisava de mão-deobra para formar as plantações e para preparar os pastos; a diária ou "jornal" era de 15 cruzeiros para os trabalhos de foice e de enxada, e de 30 cruzeiros para o trabalho de machado; as mulheres ganhavam 6 cruzeiros por dia.

A parceria, portanto, impõe ao lavrador a necessidade de recorrer ao mercado local representado pela fazenda e esta, por sua vez, determina um movimento de "concentração vicinal" 42 que se reflete no sistema de "cooperação vicinal" - o qual sobreviveu à desorganização física do bairro na medida em que não mudaram as técnicas de produção -, restringindo-o a um

42. Antonio Candido de Mello e Souza, $o p$. cit. 
43. Esse movimento migratório é acrescido pelos pequenos sitiantes que sentem a necessidade de emigrar sobretudo porque as limitaçôes territoriais impostas pela propriedade privada criam uma superpopulação artificial da pequena propriedade privada. De fato vimos que o terreno do "posseiro", agora transformado em pequeno sitiante, tendia a expelir, com regularidade quase cíclica, o seu excesso demográfico; e que as famílias expulsas se reuniam e formavam um novo "bairro". Não tendo sido introduzidas inovações técnicas para incrementar a produção, a necessidade de expelir o excesso demográfico permanece e o problemadasuperpopulação artificial da propriedade é muitas vezes resolvido pela emigração. Esse processo de expulsão é claramente ilustrado pelo caso da família B., cuja história resumimos brevemente: "Naquele mesmo ano [1935, ano em que o pai morreu] José [o filho mais velho] casou-se com Eva, uma viúva que tinha algumas terras em Taquaral. Mas a terra de Eva era ruim "e os outros tiveram grupo limitado de pessoas (cujo número é porém suficiente para garantirlhe o funcionamento) de modo a deixar ao parceiro algum tempo para trabalhar como salariado.

Se, como vimos, a fazenda representa o mercado local de mão-de-obra, permanece, porém, um mercado bastante reduzido e de salários baixíssimos; daí resulta que o lavrador é obrigado a emigrar para buscar outros mercados nos centros de trabalho que a abertura da Rio-Bahia tornou acessíveis ${ }^{43}$.

A emigração, além disso, não corresponde apenas a uma necessidade econômica, mas representa também a esperança de realizar uma aspiração ideal. De fato, se perguntarmos aos habitantes de Catulé qual é o seu maior desejo, a resposta será invariavelmente a mesma: "ter um lugar próprio para poder construir uma boa casa, fazer as lavouras a gosto, ter árvores de fruta pra ficar pro futuro. Quando a gente tem um lugar de seu pode ter tudo em casa; quando mora em lugar dos outros não tira recompensa do trabalho". Percebem, porém, perfeitamente, que não é fácil realizar esse desejo. Se alguns anos atrás não era difícil arranjar terra de ocupação, por outro lado era quase impossível conservá-la; e só o conseguia quem estivesse "disposto a brigar"; agora, não só se tornou mais árduo "tirar uma posse", mas falta também a possibilidade de economizar o suficiente para comprar um sítio. Só consegue fazer economia quem emigra; os habitantes de Catulé conhecem uma pessoa que, tendo emigrado para São Paulo, voltou depois de vários anos com o dinheiro necessário para comprar um sítio.

A emigração representa, pois, para muitos, a única esperança de realizar o mais ardente desejo. Examinando, todavia, os dados colhidos, observamos que muitos emigrantes voltam antes de transcorrido um número de anos suficiente para poupar o dinheiro necessário para comprar a terra. Indagamos quais as razões que os induziram a essa volta, pelo menos aparentemente prematura.

Tomemos como exemplo o caso de Geraldo A. P. Em 1951, Geraldo foi a Presidente Prudente com Onofre; chegou durante a colheita do algodão e começou a trabalhar imediatamente. Com os primeiros ordenados restituiu a soma que Onofre lhe emprestara para a viagem e, depois de ter gasto o estritamente necessário para se vestir, dispôs-se a economizar o máximo. Ganhava 20 cruzeiros por dia, mais cama e comida; num ano pôs de lado quatro contos. Porém, justamente nessa época, a sua família, com a de Manuel S. e as outras, teve de deixar o Urupuca e transferir-se em 1952 para Catulé onde, para poder cultivar a terra, era preciso derrubar e roçar a mata. Geraldo teve, pois, de deixar Presidente Prudente e voltar a Catulé. 
Vimos, acima, a importância do homem adulto no ciclo da agricultura de queimada; não tendo mudado a técnica que permite a adaptação ecológica do homem à terra, a situação permanece inalterada. Daí resulta que a emigração do adulto está ligada a vários fatores - por exemplo a presença de outros homens adultos - que garantam a família contra o perigo de ficar cortada da vida econômica do grupo. Confirma esta hipótese a situação familiar de Geraldo. Em 1952, Adão, seu irmão maior, casara-se e fora viver com os pais da mulher; nessa ocasiāo o outro irmão, Serafim, tinha somente 12 anos e não podia ainda trabalhar "de machado". Quando a família se transferiu para Catulé, portanto, Geraldo era o único homem adulto (e solteiro) da família; foi obrigado a voltar para poder capitalizar, mediante a prestação de obra, a força-trabalho necessária para preparar a terra. Dos 4 contos poupados, Geraldo gastou 800 cruzeiros para comprar um poncho (lembrado, talvez, do frio sofrido na mata) e usou o restante para preparar a roça em Catulé sem precisar pedir dinheiro emprestado. Teoricamente, pois, se não tivesse sido chamado, depois de um número considerável de anos teria podido juntar o dinheiro para comprar a terra.

$\mathrm{O}$ caso de Geraldo não é isolado. Como dissemos, a maior parte dos que emigram voltam depois de um período insuficiente para economizar o necessário. Parece que a média máxima desse período é de três anos. $\mathrm{O}$ longo intervalo entre a partida e o retorno do emigrante fez passar despercebido o caráter "sazonal" da emigração - entendendo-se por "estação" não o período entre a colheita e a sementeira mas o tempo que transcorre entre a derrubada e roçada da mata e o crescimento da nova capoeira. Na realidade, mesmo que tudo proceda normalmente, o emigrante que, como Geraldo, é o único homem adulto da família - seja ela composta dos pais ou da mulher e filhos -, deve voltar ao cabo de três anos aproximadamente para preparar nova terra para lavrar. De fato, embora antes de partir o lavrador deixe à família uma roça pronta para o cultivo, esta pode ser cultivada produtivamente apenas por três anos; enquanto nesse período o trabalho pode ser feito - com certa fadiga e com o auxílio de parentes e compadres - somente pela mulher, mas no momento em que se torna necessário derrubar a mata, a participação do homem é, como vimos, indispensável. Outro exemplo encontramo-lo na história de Cristina. Quando em 1948 a família voltou de Presidente Prudente, Jacinto morreu. Onofre, sendo o único homem adulto da família decidiu voltar a Presidente Prudente, mas, conta Cristina, "ele era um filho muito bom, quando foi sozinho para São Paulo plantou uma roça muito boa pra nós (a mãe, Cristina, e a irmã Germana) não sentimos falta de nada”. de sair porque a terra não dava para todos". $\mathrm{O}$ primeiro a partir foi Trajano que, depois de se casar, emigrou para São Paulo... encontrou trabalho nos campos de algodão de Presidente Prudente... onde ainda mora... Depois da partida de Trajano, a família B. deixou Taquaral por Jacutinga onde "moravam como parceiros na propriedade de M. R. Em Jacutinga Pedro casou-se e emigrou para Presidente Prudente (onde ainda reside). Antônio deixou a família (em Jacutinga) quando, tendo-se casado com a filha de um arranchado, foi trabalhar nas terras do sogro e depois, não se dando bem na casa do sogro, disse à mulher que ia trabalhar em Poté e, em vez disto, fugiu para Presidente Prudente".

junho $2008 \quad 349$ 
Voltou sozinho para ficar por pouco tempo. Mas na primeira colheita o algodão não deu bastante para vir buscá-las e esperou mais dois anos. Havia três anos quando veio para buscá-las porque havia deixado o algodão para colher, e não podia ficar para formar uma nova roça. Onofre voltou em 1951, três anos depois, isto é, quando a sua presença se tornou imprescindível.

Portanto, embora o lavrador, emigrando, tenha a esperança de passar da posição de agregado à de arranchado, de fato, na maioria dos casos, tal possibilidade não se realiza porque o caráter sazonal da emigração impóe limites de tempo demasiado reduzidos e impede a formação de um pecúlio; além disso os ganhos do emigrante - dependentes das condiçóes do mercado de trabalho - freqüentemente não compensam as desvantagens econômicas causadas pela sua ausência à família.

Todavia não se pode negar a utilidade da emigração pois, muitas vezes, quem emigra consegue ganhar, ou melhor economizar, pelo menos o suficiente para financiar os trabalhos de parceria, evitando assim ter de pedir dinheiro emprestado.

Em resumo, vimos: primeiro, como a formação da propriedade privada foi a causa primeira da desorganização do bairro; segundo, como o movimento tendente à ocupação das terras devolutas do município, pelos seus fins especulativos, favoreceu a formação de propriedades territoriais de caráter latifundiário; terceiro, como o monopólio da propriedade territorial, obrigando o lavrador a dar ao fazendeiro parte do que produz mediante técnicas ainda muito primitivas, reduziu a margem de lucro a ponto de tornar difíceis as suas relaçōes com o mercado; quarto, como, para manter tais relaçōes, o lavrador se sentiu cada vez mais atraído pelas possibilidades de trabalho remunerado oferecidas pela fazenda, e como a necessidade de se transformar em assalariado se realiza à custa do antigo sistema de "cooperação vicinal"; quinto, como, por causa das limitaçóes do mercado de trabalho local, o lavrador é obrigado a emigrar para procurar melhores centros de trabalho.

Em outras palavras, vimos como o "posseiro", tendo-se tornado parceiro, deve transformar-se em assalariado para poder permanecer parceiro e como, tendo de afrontar - por causa da desagregação do mundo estável e fechado do bairro - uma situação econômica já precária, é obrigado a deixar a sua cultura de origem expondo-se a sistemas de valores para ele de todo desconhecidos. 


\section{Mapa das Relações de Parentesco}

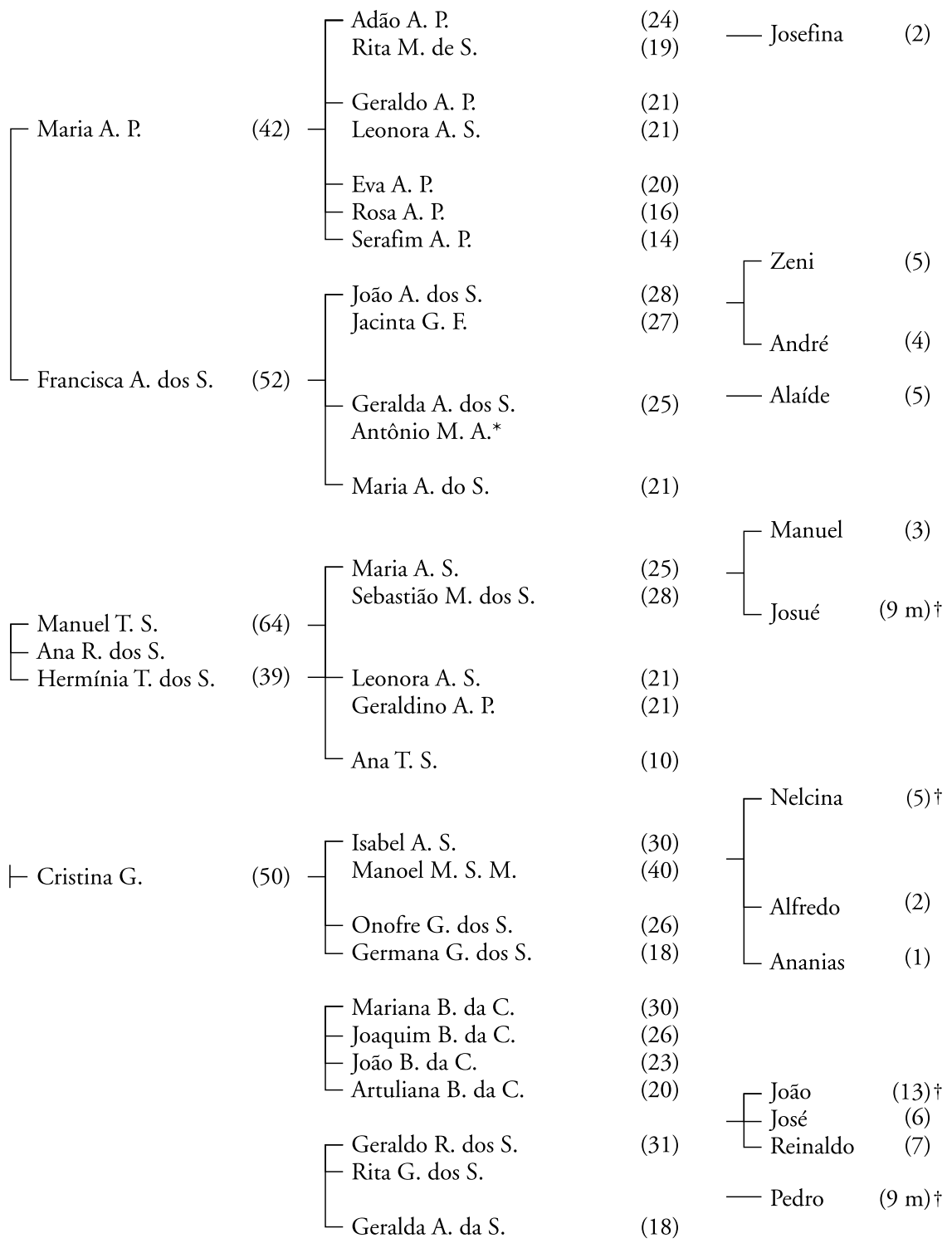

( ) Os números entre parêntese indicam a idade aproximada de cada indivíduo.

$\dagger$ A cruz indica os que foram mortos durante os acontecimentos.

* Antônio M. A. Não mora em Catulé. Emigrou para São Paulo. 


\section{Conclusões}

* Ver neste volume,

"Presença do antropólogo Carlo Castaldi no Brasil", p. 299 [N.E.].
Nos quatro artigos* que precedem estas consideraçôes finais, relatamos a história das famílias que moravam no Catulé e descrevemos a estrutura do bairro que num primeiro tempo formavam; ilustramos como o processo de formação da propriedade privada lhes causara a desorganização e como alguns de seus membros procuraram na emigração a maneira de resolver os seus próprios problemas econômicos. Vimos, além disso, qual o mecanismo da difusão do Adventismo da Promessa no grupo, quais os motivos pessoais que levaram os membros do Catulé a converter-se e quais os conflitos suscitados pela conversão. Em seguida representamos os fatos (buscando reconstruí-los com o maior número possível de particulares, em benefício dos estudiosos de psicologia) e por fim analisamos as componentes psicológicas que determinaram o tipo de percepção das pessoas envolvidas nos acontecimentos. Resta agora esclarecer de que maneira o estudo dos elementos examinados nos artigos precedentes é importante não só para melhor compreender o fenômeno religioso objeto da nossa pesquisa, isto é, a conversão de um grupo de "posseiros" que, transformados em "parceiros" deixaram o Catolicismo pelo Adventismo, mas também para determinar se tal conversão criara um ambiente favorável ao desenrolar dos fatos referidos pelos jornais em abril de 1955. Nesse contexto, a palavra "conversão" assume um significado especial: não foi, de fato, o corpus da doutrina católica, de cuja existência os habitantes do Catulé não tinham idéia, que, submetido à crítica, foi rejeitado a favor do Adventismo da Promessa. Por conseguinte, na nossa pesquisa, o Catolicismo e o Adventismo em si não formaram objeto de estudo; quando falamos de Catolicismo, pois, referimo-nos exclusivamente ao tipo de catolicismo praticado no bairro; referimo-nos, em outras palavras, a um "catolicismo de bairro", e com essa expressão queremos indicar a reelaboração feita por um grupo com certo grau de integração de folk, no caso específico o "bairro", com o fim de reforçar a própria estrutura social.

Estudando tal estrutura, de fato, vimos que somente duas cerimônias católicas, isto é, o batismo e o matrimônio, tinham uma importância fundamental, e isso porque punham em movimento o "compadrio"; este funcionava como um sistema de segurança social, sobretudo nos casos de emergência, ajudando os mais jovens, oferecendo provavelmente garantias de segurança aos velhos e sustentando os adultos em situações difíceis. À parte essas duas cerimônias, a observância das outras práticas religiosas, como 
por exemplo a confissão, a comunhão e, em geral, todas as funções eclesiásticas ligadas ao aparato religioso oficial, era mínima. Sabemos, por exemplo, que quando o grupo residia no Urupuca, o sacerdote católico visitava o povoado de Santa Cruz, centro da zona, uma ou duas vezes por ano; nessas ocasiōes, os grupos que habitavam a área iam a pé a Santa Cruz para celebrar batizados e matrimônios. $\mathrm{O}$ resto do ano, portanto, ficavam não só fisicamente isolados dos centros religiosos oficiais, como a sede da paróquia, mas permaneciam também intelectualmente isolados do ensinamento ortodoxo e da fiscalização da Igreja. Quando o grupo deixou o Urupuca, o sacerdote, embora sabendo do proselitismo da seita adventista, nunca foi visitá-los, nem visitou os grupos que se achavam em situação semelhante. A paróquia, justifica-se o padre, é grande demais para as suas forças; grupos compostos de poucas famílias moram a grandes distâncias entre si e também de Malacacheta. Visitá-los significaria viajar em lombo de burro o ano todo. Dadas as circunstâncias, surpreende que os membros do Catulé tenham continuado a considerar-se católicos, tanto mais quanto, interrogados sobre os seus velhos hábitos religiosos, admitiram que não costumavam confessar e comungar, práticas essas que, mais do que as outras, revelam a adesão aos ensinamentos da Igreja Católica. Se, pois, não eram "intimamente" católicos e se lhes faltava qualquer forma de fiscalização religiosa, em que mais podia consistir o seu catolicismo, se não justamente no uso das duas cerimônias que punham em função o compadrio? Se a isso acrescentarmos o fato de não ser propriamente católico o mundo sobrenatural do caipira - embora rico em traços culturais católicos ou designados como tais - pode-se indagar o que acontece ao "catolicismo de bairro" no momento em que o bairro se desorganiza. Sem dúvida os hábitos religiosos permanecem, mas estarão já agora despidos do antigo significado sociológico; por conseguinte o membro do bairro, mais sociologicamente do que intimamente católico, pelo fato de representar o "catolicismo de bairro" mais uma maneira de viver que uma profissão de fé, toma-se, por assim dizer, "menos" católico no momento em que já não pode comportar-se como "compadre".

Essas considerações sobre a importância funcional do "catolicismo de bairro" permitem compreender a aceitação do Adventismo por parte dos que se converteram primeiro.

O complexo processo histórico ligado à formação da propriedade privada, esboçado no primeiro artigo nosso, desorganiza um sistema de vida e impele os membros de uma sociedade fechada, como o bairro, para o traba- 
44. A dificuldade de partir é claramente indicada pelos que não o conseguiram. "Três vezes João B. vendeu tudo o que tinha para ir a São Paulo, mas quando estava na hora sempre esmorecia”. Sebastião M. dos S. "já pensou ir em São Paulo, tem muitos parentes lá mas não quis deixar a família”. Zé de Lara "quase foi uma vez, mas perdeu o trem e voltou do meio do caminho".

45. Para a importância do crédito no Catulé, ver p. 345. Sobre a importância do crédito para os sitiantes, e parceiros na zona do algodão, ver Pierre Monbeig "Pionniers et planteurs de São Paulo", Librairie Armand Colin, 1952, Paris, pp. 202207 e pp. 256-263. lho remunerado. Dadas as limitações do mercado de trabalho local, o trabalhador póe-se à procura de novos centros de trabalho. No caso particular, essa procura conduz alguns membros do grupo do Catulé a uma ativa zona algodoeira de São Paulo, Presidente Prudente, na qual, pelo que nos consta, o Adventismo da Promessa está muito difundido. Conforme o que nos foi dito pelos membros do grupo que se converteram em Presidente Prudente, a coisa que mais os impressionou no comportamento dos "crentes" foi a união que reinava entre eles; nela encontravam-se como irmãos. É lícito, pois, indagar se o emigrante do bairro, após as experiências emotivas da separação ${ }^{44}$ e devido à característica dependência revelada pelas provas psicológicas, não foi atraído pelo fato de poder estabelecer num novo grupo, tornando-se "irmão" de um vasto número de estranhos, relações semelhantes àquelas que, no bairro, se entabulavam através do compadrio. A seita religiosa, em outras palavras, poderia ter oferecido ao antigo membro do bairro a possibilidade de prolongar o tipo de relação interpessoal que lhe era familiar. Fique bem claro que esta nossa hipótese não tende a comparar a estrutura do bairro à da seita religiosa, mas tende a sublinhar a similaridade do tipo de relação em duas estruturas diversas. No nosso caso, pois, a conversão não indica o abandono de um sistema de valores em favor de outro, mas representaria a tentativa de manter, numa sociedade diversa da do bairro, o mesmo tipo de relações interpessoais. Segue-se que os emigrantes são atraídos e convencidos mais pela organização sectária do que pela doutrina adventista; dir-se-ia que qualquer outra seita que prometesse a união teria servido igualmente bem aos fins visados. Todavia, como veremos, a adesão ao Adventismo trazia consigo resultados práticos que, não sendo provavelmente considerados como frutos da conduta pessoal e sendo ao contrário atribuídos à proteção divina de que o convertido se tornava merecedor no momento em que entrava na seita, tendiam a fazer aumentar a fé na doutrina da seita.

É sabido que muitos emigrantes sofrem a experiência da emigração em termos de desorganização pessoal e são considerados pela sociedade que os recebe como "debandados", fonte contínua de perturbação. A adesão ao Adventismo impõe aos sequazes uma prática de vida dedicada ao trabalho e à religião; a pessoa que respeita os "mandamentos" não bebe, não fuma, não se entrega a divertimentos frívolos e, por conseguinte, não só poupa tempo e dinheiro, mas adquire, pelo seu bom comportamento e pela sua eficiência, as simpatias do empregador, e, em caso de necessidade, das pessoas que fazem crédito ${ }^{45}$. Todavia, embora apropriado às novas condições 
de trabalho, não se pode afirmar que o Adventismo facilite a assimilação do emigrante à nova estrutura social, e isso porque o comportamento do convertido não tem por base uma visão realística da nova sociedade e das novas relaçôes de trabalho, mas funda-se na esperança utopística de que o cumprimento escrupuloso de uma norma de vida lhe há de valer a Salvação da alma. Pelo que o contrato entre o empregado e o empregador não é objeto de discussōes e de reivindicações, mas é considerado uma "prova" que, superada com resignação, lhe garantirá um bom lugar na glória do segundo advento. Enquanto, pois, o Adventismo da Promessa ajuda o ex-posseiro a adaptar-se à nova sociedade capitalista, que transbordando o submergiu, a orientação escatológica da seita põe obstáculo a qualquer forma de participação ativa e de verdadeira assimilação na nova sociedade; diríamos mesmo que impede a formação de uma consciência realística da experiência histórica por ele vivida.

Não sabemos que proporções assume na vida dos "crentes" de Presidente Prudente esse aspecto escatológico, pois o proselitismo de qualquer religião sublinha aspectos diversos conforme os grupos a que se dirige; provavelmente é atenuado pelos cuidados que as atividades econômicas exigem; sabemos em todo o caso que isso ocupava a mente dos habitantes do Catulé e tinha uma forte influência na sua visão do mundo. Como vimos, ao voltar ao Catulé, Onofre se faz prosélito de uma prática de vida que, favorecendo um ritmo de trabalho mais intenso e uma economia mais estreita, estabiliza a economia do grupo mais do que a melhora propriamente ("o trabalho rendia mais", como nos disse um dos nossos informantes), dá novo vigor e significado às práticas de auxílio mútuo (que sobreviveu por se terem mantido as técnicas de produção) e torna ainda mais estreita a equiparação "compadre-irmão", uma vez que, no Catulé, todos os “irmãos" vivem da mesma maneira ${ }^{46}$. A supra-estrutura do grupo que Onofre reorganiza, porém, é muito diversa da do bairro; o antigo bairro representava, pelo seu isolamento, o inteiro mundo caipira - um mundo sem inquietudes celestes -, ao passo que o novo grupo representa um compromisso, de caráter temporário, com o restante do mundo, à espera do segundo advento. O Adventismo, de fato, está numa posição negativa em relação à realidade social em formação, porque lhe impede a compreensão, canalizando para a salvação a atenção dos seus sequazes. Sobre esse ponto, a documentação é riquíssima e consistente, também no caso de problemas vitais, como o fundiário. A maneira por que a terra é distribuída é injusta, dizem os habitantes do Catulé; o governo, "este homem com teoria de mandar", teria naturalmente jeito de
46. Ao passo que em Presidente Prudente consideravam-se "irmãos" também pessoas de condições de vida muito diversas. 
mudar esse estado de coisas, mas as suas leis "não prestam para os pobres", e essa reflexão não é seguida de um impulso político mas de uma atitude escatológica: "para livrar-se da penúria do mundo só a salvação... os que se salvarão irão participar do Jardim do Éden, como Adão e Eva antes do pecado. Quem não é salvo vai para o inferno, onde os que não foram salvos serão queimados, mas não ficam penando não. Se o pobre agüentar sem perder a paciência ganhará tanto quanto o rico", o qual, pela sua riqueza, está mais exposto à tentação (“a riqueza é mais milagre de Satanás que de Deus"); pelo que "ninguém pode se queixar de ser pobre"; o pobre que se comporta como um bom irmão e é puro de coração, salvar-se-á.

A pureza de coração mantém-se mediante a confissão, e é confirmada pela descida do Espírito Santo. No tempo da nossa visita ao Catulé, como já tivemos ocasião de expor, as práticas adventistas haviam sido proibidas; não nos foi, pois, possível observar diretamente o fenômeno de possessão do Espírito Santo; sabemos porém que assumia valor de testemunha indiscutível da pureza da vida interior dos "crentes"; o fato de ter dado a essa experiência psicológica um valor social induzia além disso as pessoas do Catulé a abandonarem-se a ela com fervor, o que, em vista dos resultados dos testes, não podia ser aconselhável. Além disso, se, de um lado, a presença do Espírito Santo testemunha pureza de coração, de outro, a confissão é necessária continuamente para defender-se da tentação, obra de Satanás ("se não existisse Satanás não existiria o pecado"). Satanás, portanto, entra a fazer parte da vida privada de cada um, e dele não nos podemos defender fazendo simplesmente o sinal da cruz.

Para resumir brevemente, o tipo de relaçôes interpessoais que se estabeleciam no bairro facilitava o ingresso do ex-posseiro na seita religiosa. Por sua vez, a seita prega normas de vida que, se, de um lado, facilitam a adaptação do indivíduo às novas condições de trabalho, de outro, devido à sua orientação escatológica, não favorecem uma tomada de consciência realística e uma participação ativa na nova sociedade. A atividade religiosa de Onofre, de regresso ao Catulé, cria uma sociedade utopística que fomenta a emotividade, e nesse sentido só pode ser prejudicial a pessoas tais como os habitantes do Catulé.

Destas considerações parece-nos poder concluir que o Adventismo da Promessa, embora não tenha sido a causa determinante dos fatos estudados, criou condições que favoreceram o desenrolar dos acontecimentos. Porém, é preciso acrescentar que essas condiçôes, sem o tipo de indivíduos que as viveram, dificilmente teriam evocado a presença do demônio no Catulé. 


\section{Resumo}

\section{A aparição do demônio no Catulé}

Carlos Castaldi faz uma "descrição densa" da tragédia ocorrida no município de Malacacheta, em Minas Gerais, na Fazenda São João da Mata, no ano de 1955. Em abril desse ano, quatro crianças foram assassinadas por um grupo de parceiros convertidos à Igreja Adventista da Promessa, por estarem, segundo acreditavam, possuídas pelo diabo. Em seguida ao fato, por iniciativa conjunta da revista Anhembi, do Instituto Nacional de Estudos Pedagógicos e do Departamento de Sociologia da Faculdade de Filosofia da USP, o sociólogo, a antropóloga Eunice Ribeiro (depois Durham) e a psicóloga Carolina Martuscelli seguiram para o local com o objetivo de explicar o ocorrido, ali permanecendo entre 11 de julho e 8 de agosto. $\mathrm{O}$ texto relaciona o fato às mudanças sociais que teriam desestruturado o grupo, dialogando diretamente com a tese Os parceiros do Rio Bonito, defendida por Antonio Candido em 1954. Palavras-chave: Bairros rurais; Compadrio; Anomia; Conversão religiosa.

\section{Abstract}

The demon's apparition in Catulé

Carlos Castaldi provides a 'dense description' of the tragedy that took place in the municipality of Malacacheta, in Minas Gerais, on the São João da Mata Farm in 1955. In April of that year, four children were murdered by a group of sharecroppers converted to the Adventist Church of the Promise, believing that the children had become possessed by the devil. After the incident, a joint initiative of the magazine Anhembi, the National Institute of Pedagogical Studies and the Department of Sociology of the São Paulo University Faculty of Philosophy led to the visit of a team formed by sociologist Carlos Castaldi, anthropologist Eunice Ribeiro (later Durham) and psychologist Carolina Martuscelli, who stayed at the locale from July $11^{\text {th }}$ to August $8^{\text {th }}$ with the aim of discovering the reasons behind the event. The text relates the incident to the social changes that had led to the destructuring of the group, dialoguing closely with the doctoral thesis The sharecroppers of the Bonito River, completed by Antonio Candido in 1954.

Keywords: Rural districts; Compaternity; Anomy; Religious conversion. 